\title{
Measurement report: The importance of biomass burning in light extinction and direct radiative effect of urban aerosol during the COVID-19 lockdown in China
}

Jie Tian ${ }^{1,2}$, Qiyuan Wang ${ }^{1,2,3}$, Huikun Liu ${ }^{1}$, Yongyong Ma ${ }^{4}$, Suixin Liu ${ }^{1,2}$, Yong Zhang ${ }^{1}$, Weikang Ran ${ }^{1}$, 5 Yongming $\mathrm{Han}^{1,2,3}$, and Junji $\mathrm{CaO}^{5}$

${ }^{1}$ State Key Laboratory of Loess and Quaternary Geology, Institute of Earth Environment, Chinese Academy of Sciences, Xi'an 710061, China

${ }^{2}$ CAS Center for Excellence in Quaternary Science and Global Change, Xi' an 710061, China

${ }^{3}$ Guanzhong Plain Ecological Environment Change and Comprehensive Treatment National Observation and Research Station,

10 Xi'an 710061, China

${ }^{4}$ Meteorological Institute of Shaanxi Province, Xi'an 710015, China

${ }^{5}$ Institute of Atmospheric Physics, Chinese Academy of Sciences, Beijing 100029, China

Correspondence: Qiyuan Wang (wangqy@ieecas.cn) and Junji Cao (jjcao@mail.iap.ac.cn)

15 Abstract. To mitigate climate change in China, a better understanding of optical properties of aerosol is required due to the complexity in emission sources. Here, an intensive real-time measurement was conducted in an urban area of China before and during the lockdown of Coronavirus Disease 2019 (COVID-19), to explore the impacts of anthropogenic activities on aerosol light extinction and direct radiative effect (DRE). The mean light extinction coefficient $\left(b_{\text {ext }}\right)$ reduced from $774.7 \pm 298.1 \mathrm{Mm}^{-1}$ during the normal period to $544.3 \pm 179.4 \mathrm{Mm}^{-1}$ during the lockdown period. The generalized

20 addictive model analysis indicated that the large decline of $b_{\text {ext }}(29.7 \%)$ was entirely attributed to the sharp reductions in anthropogenic emissions. Chemical calculation of $b_{\text {ext }}$ based on the ridge regression analysis showed that organic aerosol (OA) was the largest contributor to $b_{\text {ext }}$ in both periods (45.1-61.4\%), and contributions of two oxygenated OAs to $b_{\text {ext }}$ increased by 3.0-14.6\% during the lockdown. A hybrid environmental receptor model combining with chemical and optical variables identified six sources of $b_{\text {ext. }}$. It was found that $b_{\text {ext }}$ from traffic-related emission, coal combustion,

25 fugitive dust, nitrate plus secondary OA (SOA) source, and sulfate plus SOA source decreased by 21.4-97.9\% in the lockdown, whereas $b_{\text {ext }}$ from biomass burning increased by $27.1 \%$ mainly driven by undiminished needs of residential cooking and heating. The atmospheric radiative transfer model was further used to illustrate that biomass burning instead of traffic-related emission became the largest positive effect $\left(10.0 \pm 10.9 \mathrm{~W} \mathrm{~m}^{-2}\right)$ on aerosol DRE in the atmosphere during the lockdown. Our study provides insights into aerosol $b_{\text {ext }}$ and DRE from anthropogenic sources, and the results

30 implied the importance of biomass burning for tackling climate change in China in the future. 


\section{Introduction}

The abrupt outbreak of Coronavirus Disease 2019 (COVID-19) since December of 2019 caused unprecedented economic and social disruption (Yao et al., 2020). Chinese government implemented the city lockdown and a series of strict restrictions on travel, transports, factories, and constructive activities for numerous cities in China to curb the virus spread among humans. This provides a rare opportunity to investigate the impacts of anthropogenic activities on air pollution in China. Recent aerosol studies are conducted during the lockdown with a major focus on primary emissions and secondary formation, and most of them have revealed changes in aerosol compositions, sources, and processes under emission control measures (Le et al., 2020; Li et al., 2020; Wang et al., 2020a; Wang et al., 2020c; Zhao et al., 2020; Zheng et al., 2020). However, only a few studies are conducted to explore the link of chemical constituents in aerosol with light absorption during the lockdown (Chen et al., 2020; Lin et al., 2021; Xu et al., 2020). The influences of reduced anthropogenic activities on the variations of aerosol optical properties and direct radiative effect (DRE) are less understood.

Atmospheric aerosols alter the radiative energy budget by directly scattering and absorbing solar and terrestrial radiation to affect the globe climate change (Bellouin et al., 2013; Yao et al., 2017). The spatiotemporal variations of aerosol

45 optical properties (e.g., light scattering coefficient $\left(b_{\text {scat }}\right.$ ), light absorption coefficient $\left(b_{\text {abs }}\right)$, light extinction coefficient $\left(b_{\text {ext }}\right)$, and single scattering albedo (SSA)) that highly depended on their chemical compositions and sources (Malm and Hand, 2007; Tao et al., 2014), can result in uncertainties in estimating aerosol DRE (IPCC, 2013; Ma et al., 2012). Therefore, distinguishing chemical composition- and source-specific aerosol optical properties from a mixture of aerosols in the atmosphere would make a better understanding of the climate change during the COVID-19 lockdown.

50 The relationship between aerosol optical coefficients and chemical compositions can be built by the Interagency Monitoring of Protected Visual Environments algorithm and multiple linear regression (MLR) (Deng et al., 2016; Malm and Hand, 2007; Shen et al., 2014; Tao et al., 2014, 2015). However, previous studies often regarded organic aerosol (OA) as a whole light scattering component only. In reality, there are some OA components can absorb light, which is collectively termed as brown carbon (BrC) (Andreae and Gelencsér, 2006). The DRE caused by BrC has been reported 55 to be nonnegligible (e.g., $0.04 \mathrm{~W} \mathrm{~m}^{-2}$ to $0.57 \mathrm{~W} \mathrm{~m}^{-2}$ ) (Feng et al., 2013; Lin et al., 2014; Wang et al., 2014). Furthermore, the optical properties of OA can vary widely due to the complexity of OA components associated with primary sources, formation pathways, and aging processes (Laskin et al., 2015). For instance, primary OA (POA) from anthropogenic sources (e.g., biomass burning and coal combustion) usually has different mass scattering and absorption efficiencies (MSE and MAE) in the atmosphere compared to secondary OA (SOA) formed though photochemical or aqueous-phase 60 oxidations (Han et al., 2015; Qin et al., 2018). Therefore, investigating POA and SOA contributions to aerosol light scattering and absorption would reduce uncertainties in chemical apportionment of aerosol optical properties. 
Previous studies have been conducted on the aerosol optical source apportionment. According to the multi-wavelength aethalometer measurement, the source of aerosol $b_{\text {abs }}$ can be investigated by exploiting the differences in absorption spectra of light-absorbing materials (Herich et al., 2011; Sandradewi et al., 2008; Zotter et al., 2017). In this method, the aerosol absorption near ultraviolet and short-visible regions of the spectrum from biomass burning is assumed to be enhanced because of $\mathrm{BrC}$ emitted, compared to that from fossil fuel combustion (Kirchstetter et al., 2004; Tian et al., 2019). This makes it possible to derive their contributions to light absorption by using the specific source absorption Ångström exponent (AAE), but the so-called "aethalometer model” could not distinguish as many sources resolved by receptor models due to the similar optical properties of the aerosol sources (Saarikoski et al., 2021). In contrast, receptor models can be utilized to resolve multiple optical source apportionment of aerosol. Several studies used a combination of the receptor model and MLR to indirectly identify sources of aerosol $b_{\text {scat }}, b_{\text {abs, }}$, and $b_{\text {ext }}$ (Cao et al., 2012; Tian et al., 2020; Zhou et al., 2017). For example, Zhou et al. (2017) firstly used positive matrix factorization analysis to quantify the mass contributions of aerosol from secondary aerosol, biomass burning, traffic-related emissions, and coal burning based on the sole chemical species, and then the MLR was used to apportion the contribution of each source to $b_{\text {scat }}$ and

$75 b_{\text {abs. }}$ In addition, recent studies have attempted to conduct direct optical source apportionment by combining aerosol chemical species with optical coefficients in one receptor model (Forello et al., 2019; Q. Wang et al., 2020b; Xie et al., 2019). This promising method can provide both chemical and optical profiles in each source to improve the performance of source identification, and may eliminate potential uncertainties caused by the indirect approach.

The Fenwei Plain is designated as the key regions of pollution treatment in "three-year action plan to fight air pollution"

80 implemented by the Chinese State Council in 2018. As one of megacities in this plain, Xi' an has been facing severe air pollution problem, especially in winter (Niu et al., 2016; Wang et al., 2015). Here, we conducted highly time-resolved aerosol $b_{\text {scat }}$ and $b_{\text {abs }}$ measurements in Xi'an before and during the city lockdown in China. The main objectives are to (1) characterize the changes of aerosol optical properties since COVID-19 lockdown; (2) quantify the contributions of individual chemical composition and specific source to $b_{\text {ext }}$; and (3) evaluate source-specific aerosol DRE based on a

85 radiative transfer model. This study provides insights into the response of aerosol $b_{\text {ext }}$ and DRE to anthropogenic emission sources, which is a scientific basis for making future emission control policies to deal with climate change in China.

\section{Methodology}

\subsection{Sampling site and period}

90 Intensive measurements of aerosol optical properties were conducted at an urban site located at Guanzhong Plain Ecological Environment Change and Comprehensive Treatment National Observation and Research Station, southwest 
of Xi'an downtown $\left(34^{\circ} 13^{\prime} \mathrm{N}, 108^{\circ} 52^{\prime} \mathrm{E}\right.$, Figure S1). All instruments were placed at the rooftop of an office building ( $10 \mathrm{~m}$ above the ground) and approximately $30 \mathrm{~m}$ from the nearest traffic road. Detailed description of the sampling site can be found in Tian et al. (2021). In this study, the sampling campaign consisted of two distinct periods: normal period (1 to 23 January, 2020) and COVID-19 lockdown period (27 January to 7 February, 2020). Three days of 24 to 26 January, 2020 were excluded due to the intensive influence of fireworks.

\subsection{Measurements}

2.2.1 Real-time measurements of $b_{\text {scat }}$ and $b_{\text {abs }}$

A single wavelength integrating nephelometer (Aurora 1000, Ecotech, Melbourne, Australia) was carried out to measure aerosol $b_{\text {scat }}$ at a wavelength of $525 \mathrm{~nm}$ with 5-min time resolution. In the measurement volume, the ambient air sampled with a flow rate of $5 \mathrm{~L} \mathrm{~min}^{-1}$ was illuminated by the light source, that only light scattered at scattering angles between $10^{\circ}$ and $170^{\circ}$ can reached the photomultiplier tube. Thereafter, $b_{\text {scat }}$ can be calculated by the proportion of the electrical signals produced by the photomultiplier tube. Span calibration was made using $\mathrm{CO}_{2}$ to ensure accuracy of the instrument before sampling, and zero calibration were performed twice each day with particle-free air to subtract the Rayleigh

105 scattering. More detailed principles of the Aurora 1000 have been described in elsewhere (Chamberlain-Ward and Sharp, 2011).

Aerosol $b_{\text {abs }}$ at wavelengths of $370 \mathrm{~nm}, 470 \mathrm{~nm}, 520 \mathrm{~nm}, 590 \mathrm{~nm}, 660 \mathrm{~nm}$, and $880 \mathrm{~nm}$ were measured by a newly developed Aethalometer (model AE33, Magee Scientific, Berkeley, CA, USA) with 1-min time resolution. Briefly, the model AE33 was the filter-based absorption photometer that simultaneously measured the light attenuation transmitted

110 through two parallel spots of the aerosol filter with $3.85 \mathrm{~L} \mathrm{~min}^{-1}$ and $1.15 \mathrm{~L} \mathrm{~min}^{-1}$, respectively. Based on "dual-spot" measurements, it used a real-time loading effect compensation algorithm to eliminate the nonlinear loading effect as increasing deposition amount of aerosol on the filter. Additionally, a factor of 2.14 was used in the model AE33 to automatically modify the quartz filter matrix scattering effect. A detailed description of this instrument can be found in Drinovec et al. (2015).

115 Both of the Aurora 1000 and model AE33 instruments equipped with a $\mathrm{PM}_{2.5}$ cyclone separator in the sampling inlet to remove particles larger than $2.5 \mu \mathrm{m}$, and a Nafion ${ }^{\circledR}$ dryer (MD-700-24S, Perma Pure, Inc., Lakewood, NJ, USA) to retain particles (relative humidity $<40 \%$ ) before entering these instruments. The amount of $b_{\text {ext }}$ in this study was defined as the sum of $b_{\text {scat }}$ at $525 \mathrm{~nm}$ and $b_{\text {abs }}$ at $520 \mathrm{~nm}$.

\subsubsection{Complementary data}

120 A quadrupole aerosol chemical speciation monitor (Q-ACSM, Aerodyne Research Inc., Billerica, Massachusetts, USA) and a Xact 625 ambient metals monitor (Xact 625i, Cooper Environmental Services, Beaverton, OR, USA) were operated 
to obtain chemical composition characteristics (Furger et al., 2020; Ng et al., 2011). The Q-ACSM measured concentrations of non-refractory species in $\mathrm{PM}_{1}\left(\mathrm{NO}_{3}{ }^{-}, \mathrm{SO}_{4}{ }^{2-}, \mathrm{NH}_{4}{ }^{+}, \mathrm{Cl}^{-}\right.$, and $\left.\mathrm{OA}\right)$, and $\mathrm{OA}$ was further resolved into POA, less-, and more-oxidized oxygenated OA (LO-OOA and MO-OOA). Detail information on Q-ACSM data process and source apportionment of OA can be found in our previous paper (Tian et al., 2021). The Xact 625i quantified hourly element concentrations through X-ray fluorescence analysis, including $\mathrm{Si}, \mathrm{K}, \mathrm{Ca}, \mathrm{Cr}, \mathrm{Mn}, \mathrm{Fe}, \mathrm{Zn}, \mathrm{As}, \mathrm{Se}, \mathrm{Ba}, \mathrm{Hg}$, and $\mathrm{Pb}$. Additionally, $\mathrm{BC}$ concentration was calculated using $b_{\text {abs }}$ at $880 \mathrm{~nm}$ (Kirchstetter et al., 2004). Online $\mathrm{PM}_{2.5}$ and $\mathrm{NO}_{x}$ concentrations were obtained from the Department of Ecology and Environment of Shaanxi Province. More detailed descriptions of these complementary data can be found in Table S1.

\subsection{Meteorological conditions separation}

A generalized addictive model (GAM) combined with integrated smoothness estimation was used to establish the relationship between $b_{\text {ext }}$ and several meteorological parameters as follows (Wood, 2004):

$$
\ln b_{\mathrm{ext}}(i)=\sum_{j=1}^{7} f_{j}\left(\mathrm{MP}_{j}(i)\right)+\beta_{0}+\mathrm{e}_{i}
$$

where $b_{\text {ext }}(i)$ is the $b_{\text {ext }}$ in $\mathrm{Mm}^{-1}$ averaged over the $i^{\text {th }}$ hour; $\mathrm{MP}_{j}$ represents the $j^{\text {th }}$ meteorological parameter, such as wind speed, wind direction, relative humidity, temperature, pressures, dew point, and planetary boundary layer height, where the data sources can be found in Table $\mathrm{S} 1 ; f$ corresponds to the smooth function describing the association between $b_{\text {ext }}$ and meteorological parameters; $\beta_{0}$ is the model intercept; and $\mathrm{e}_{i}$ is the regression residuals which is assumed to be normally distributed.

Based on the R package "mgcv" (Wood, 2017), the whole campaign dataset was divided into three parts: a model data

140 (80\% of data during the normal period) for establishing the $b_{\text {ext }}$ GAM, a test data ( $20 \%$ of data during the normal period) for verifying the accuracy of the model, and a forecast data (100\% of data during the lockdown period) for estimating the contributions of meteorological conditions and emissions on $b_{\text {ext }}$ reduction.

\subsection{Chemical calculation of $b_{\text {scat }}$ and $b_{\text {abs }}$}

In view of POA and SOA with nonnegligible light scattering and absorbing abilities, the amount of $b_{\text {scat }}$ and $b_{\text {abs }}$

145 associated with individual chemical species can be estimated statistically using the ridge regression method:

$$
\begin{gathered}
b_{\text {scat }}=\mathrm{a}_{1}\left[\mathrm{NH}_{4} \mathrm{NO}_{3}\right]+\mathrm{a}_{2}\left[\left(\mathrm{NH}_{4}\right)_{2} \mathrm{SO}_{4}\right]+\mathrm{a}_{3}[\text { fine soil }] \\
+\mathrm{a}_{4}[\mathrm{POA}]+\mathrm{a}_{5}[\mathrm{LO}-\mathrm{OOA}]+\mathrm{a}_{6}[\mathrm{MO}-\mathrm{OOA}]+\mathrm{c}_{1} \\
b_{\text {abs }}=\mathrm{b}_{1}[\mathrm{BC}]+\mathrm{b}_{2}[\mathrm{POA}]+\mathrm{b}_{3}[\mathrm{LO}-\mathrm{OOA}]+\mathrm{b}_{4}[\mathrm{MO}-\mathrm{OOA}]+\mathrm{c}_{2}
\end{gathered}
$$


where $b_{\text {scat }}$ and $b_{\text {abs }}$ are given in unit of $\mathrm{Mm}^{-1}$; the bracket notation [] represents the specific chemical species concentration in $\mu \mathrm{g} \mathrm{m}^{-3}$; the $\mathrm{a}_{i}$ and $\mathrm{b}_{i}(i=1-6)$ describe the MSE and MAE of each chemical species in unit of $\mathrm{m}^{2} \mathrm{~g}^{-1}$, respectively; and $c_{i}(i=1$ or 2$)$ is the constant. In equation (2), the concentrations of $\left[\mathrm{NH}_{4} \mathrm{NO}_{3}\right],\left[\left(\mathrm{NH}_{4}\right)_{2} \mathrm{SO}_{4}\right]$, and [fine soil] were calculated using 1.29 $\times\left[\mathrm{NO}_{3}{ }^{-}\right], 1.35 \times\left[\mathrm{SO}_{4}{ }^{2-}\right]$, and [Fe]/0.032, respectively (Chow et al., 2015; CNEMC, 1990). In equation (3), $b_{1}$ was calculated by absorption Ångström exponent method, and the detailed description can be seen in Text S1.

\subsection{Hybrid environmental receptor model (HERM) for source apportionment}

The source apportionment of $b_{\text {ext }}$ was performed with HERM which is a newly developed bilinear model (Chen and Cao, 2018). Briefly, the HERM solves non-negative matrices of unknown factor profiles and contributions with a pre-set number of factors $\mathrm{K}$ by iteratively minimizing the object function $\mathrm{Q}$ defined as follows:

$$
\mathrm{Q}=\sum_{j=1}^{\mathrm{J}} \sum_{i=1}^{\mathrm{I}} \frac{\left(x_{i j}-\sum_{k=1}^{\mathrm{K}} g_{i k} f_{k j}\right)^{2}}{\sigma_{x_{i j}}^{2}+\sum_{k=1}^{\mathrm{K}}\left(g_{i k}^{2} \sigma_{f_{k j}}^{2}+\delta_{i k} \sigma_{x_{i j}}^{2}\right)}
$$

160

where I, J, and $\mathrm{K}$ are the number of samples, aerosol variables, and factors, respectively; the indices of $i, j, k$ represent the sample, aerosol variable, and factor, respectively; $x_{i j}$ is the measured ambient data spectral matrix; $f_{k j}$ is the factor profile matrix; $g_{i k}$ is factor contribution matrix; $\sigma_{x_{i j}}$ and $\sigma_{f_{k j}}$ represent the error in measured ambient data and variability in constrained factor profile, respectively; $\delta_{i k}$ is set to 0 or 1 depending on whether the $k^{\text {th }}$ factor profile is constrained or unconstrained, respectively.

165 In this study, both chemical species $\left(\mathrm{PM}_{2.5}, \mathrm{NO}_{3}{ }^{-}, \mathrm{SO}_{4}{ }^{2-}, \mathrm{NH}_{4}{ }^{+}, \mathrm{Cl}^{-}, \mathrm{BC}, \mathrm{POA}, \mathrm{LO}-\mathrm{OOA}, \mathrm{MO}-\mathrm{OOA}, \mathrm{Si}, \mathrm{K}, \mathrm{Ca}, \mathrm{Cr}, \mathrm{Mn}\right.$, $\mathrm{Fe}, \mathrm{Zn}, \mathrm{As}, \mathrm{Se}, \mathrm{Ba}, \mathrm{Hg}$, and $\mathrm{Pb}$ in $\mu \mathrm{g} \mathrm{m}^{-3}$ ) and optical variables $\left(b_{\text {scat }}\right.$ and $b_{\text {abs }}$ in $\mathrm{Mm}^{-1}$ ) were used as input data for the HERM analysis. The uncertainties of hourly ambient data except elements were introduced by the standard deviation of samples with higher time resolution (<1-hour); the uncertainty of the element was estimated using its concentration, the default analytical relative error (10\%) (Rai et al., 2020), and method detection limit (MDL) (Norris et al., 2014) (Text

170 S2). All input variables were classified as strong due to the high signal-to-noise (SNR > 2). Here, the HERM had predetermined: (1) the $i^{\text {th }}$ sample was excluded from source apportionment when missing values occurred in variables; (2) $\mathrm{PM}_{2.5}$ value in factor profile was set to unity as a reference standard for both chemical and optical variables.

A range of factor numbers from 2 to 8 was selected to run in the HERM software with completely unconstrained factor profiles, and diagnostic plots are detailed in the supplementary material (Text S3 and Figure S2-S7). The 6-factor

175 solution without mixed source was found to be the optimal solution based on multiple criteria including (1) variations in $\mathrm{Q} / \mathrm{Q}_{\exp }$ that can be used as a metric for choosing the best number of resolved factors (Ulbrich et al., 2009); (2) physical 
meaningfulness of distinct factor profiles and explained variations (EV) of variables; (3) agreement between the measured and modeled values; and (4) good correlations with external and internal tracers. Detailed information on the final selected factor profiles and contributions are presented in Section 3.4.

\subsection{DRE calculations}

The Santa Barbara DISORT Atmospheric Radiative Transfer (SBDART) developed by Institute for Computational Earth System Science, University of California was utilized to estimate the source-specific aerosol DRE. It can calculate the downwelling and upwelling radiative flux $\left(\mathrm{F}_{\text {down }}\right.$ and $\left.\mathrm{F}_{\mathrm{up}}\right)$, in which difference indicates the net radiative flux $\left(\Delta \mathrm{F}=\mathrm{F}_{\text {down }}\right.$ $-F_{u p}$ ). A detailed description of the SBDART can be found in Ricchiazzi et al. (1998). Based on the optical source apportionment results, the SBDART model input values of aerosol optical depth, SSA, asymmetry factor, and optical coefficients were retrieved using the Optical Properties of Aerosol and Cloud (OPAC) model (Hess et al., 1998). The aerosol DRE can be calculated as follows:

$$
\begin{gathered}
\mathrm{DRE}_{\text {atmosphere }}=\mathrm{DRE}_{\text {top }}-\mathrm{DRE}_{\text {surface }} \\
\mathrm{DRE}_{\text {top }}=\Delta \mathrm{F}_{\text {top }}(\text { with aerosol })-\Delta \mathrm{F}_{\text {top }}(\text { without aerosol }) \\
\mathrm{DRE}_{\text {surface }}=\Delta \mathrm{F}_{\text {surface }}(\text { with aerosol })-\Delta \mathrm{F}_{\text {surface }}(\text { without aerosol })
\end{gathered}
$$

where the indices of atmosphere, top, and surface indicate the DRE in the atmosphere, at the top of the atmosphere, and the earth's surface, respectively; $\Delta \mathrm{F}$ (with aerosol) and $\Delta \mathrm{F}$ (without aerosol) represent the net radiative flux with and without aerosol, respectively.

\section{Results and discussion}

\section{3.1 General descriptions of aerosol optical properties}

The temporal variations of hourly mean $b_{\text {scat, }}, b_{\mathrm{abs}}, b_{\mathrm{ext}}$, and SSA together with $\mathrm{PM}_{2.5}$ mass concentrations for the entire sampling period are depicted in Figure S8, while a statistics summary of optical and chemical parameters during the normal and COVID-19 lockdown periods is shown in Table 1. The optical coefficients decreased dramatically in accord with the significant reduction of $\mathrm{PM}_{2.5}$ since stringent control measures on emission sources implemented during the lockdown period (Tian et al., 2021; Zheng et al., 2020). The mean values of $b_{\text {scat }}, b_{\text {abs }}$, and $b_{\text {ext }}$ during the normal period were $688.1 \pm 261.4 \mathrm{Mm}^{-1}, 86.6 \pm 43.0 \mathrm{Mm}^{-1}$, and $774.7 \pm 298.1 \mathrm{Mm}^{-1}$, respectively, which is consistent with the values $\left(657.4 \pm 436.9 \mathrm{Mm}^{-1}, 104.0 \pm 69.6 \mathrm{Mm}^{-1}\right.$, and $\left.761.4 \pm 506.5 \mathrm{Mm}^{-1}\right)$ reported previously in winter of 2009 in Xi' an (Cao et al., 2012), even though a series of nationwide air quality standards and long-term pollution control policies have been 
implemented in the 74 major cities since 2013 (Zheng et al., 2018). Comparatively, the kind of control measures aiming

to curb the outbreaks did not last long, but it was unprecedentedly strictest in China. The large decreases (27.6-47.0\%) were found in $b_{\text {scat, }} b_{\mathrm{abs}}$, and $b_{\text {ext }}$ in the lockdown $\left(498.4 \pm 159.0 \mathrm{Mm}^{-1}, 45.9 \pm 22.9 \mathrm{Mm}^{-1}\right.$, and $544.3 \pm 179.4 \mathrm{Mm}^{-1}$, respectively), providing insights into the role of anthropogenic emissions on aerosol optical properties.

The SSA defined as the ratio of $b_{\text {scat }}$ to $b_{\text {ext }}$ increased from $0.89 \pm 0.03$ during the normal period to $0.92 \pm 0.02$ during the lockdown period. As presented in Figure S9a and b, SSA showed linear increases with the mass fractions of secondary inorganic aerosol $\left(\mathrm{SIA}=\mathrm{NH}_{4} \mathrm{NO}_{3}+\left(\mathrm{NH}_{4}\right)_{2} \mathrm{SO}_{4}\right)$ to $\mathrm{PM}_{2.5}\left(\mathrm{R}^{2}=0.83-0.84\right)$ and SOA $(\mathrm{SOA}=\mathrm{LO}-\mathrm{OOA}+\mathrm{MO}-\mathrm{OOA})$ to OA $\left(\mathrm{R}^{2}=0.94-0.99\right)$, indicating an enhanced role of secondary formation in the lockdown. In addition, the correlations of SSA and the ratio of LO-OOA to MO-OOA were established to reveal a more complex influence of SOA on SSA (Figure S9c), which showed obviously negative relationships $\left(\mathrm{R}^{2}=0.69-0.79\right)$. It indicated that SSA can be impacted by the degree of oxidation on aerosol, and higher scattering and lower absorption abilities are usually found for more oxidized OA (Han et al., 2015; Lee et al., 2014).

\subsection{Effects of emission reduction and meteorological conditions on reduced $b_{\text {ext }}$}

Figure 1 shows the time series of the measured and GAM-predicted $b_{\text {ext }}$ for the model data, test data, and forecast data. As shown in Table S2 and S3 the constructed GAM with adjusted $\mathrm{R}^{2}$ value (0.569) can explain $56.9 \%$ of the variation in $b_{\text {ext }}$ after incorporating the nonlinear relationships between optical and meteorological parameters. Independent smoothed meteorological variables of the model were statistically significant by according to $p$ values $(<0.05)$ from $\mathrm{F}$ test. Concurvity indices between each independent smoothed parameter were within 0.5 , indicating there was no serious multicollinearity (Schimek, 2009).

Before applying the constructed GAM to predict the $b_{\text {ext }}$ during the lockdown period, the cross-validation test was used to evaluate the model. For the test data ( $20 \%$ of data during the normal period), the $\mathrm{R}^{2}$ value of the linear regression and index of agreement (IOA) (Wu et al., 2018) between the measured and GAM-predicted $b_{\text {ext }}$ was 0.80 and 0.91 , respectively, suggesting a good performance of the constructed GAM. Therefore, the difference between the measured and GAM-predicted $b_{\text {ext }}$ in the lockdown can be attributed to emission reduction through the implementation of stringent control measures on emission sources. The emission reduction decreased $b_{\text {ext }}$ by $294.6 \mathrm{Mm}^{-1}$ during the lockdown period, higher than the decline of measured $b_{\text {ext }}\left(230.4 \mathrm{Mm}^{-1}\right)$ from normal to lockdown periods. It is indicated that the meteorological conditions enhanced $b_{\text {ext }}$ by $64.2 \mathrm{Mm}^{-1}$ during the lockdown period, further reflecting the effective control of anthropogenic emissions. 


\subsection{Contribution of chemical components to $b_{\text {ext }}$}

Table 2 presents the estimated MSE and MAE of individual chemical component during the normal and lockdown periods. The MSEs of $\mathrm{NH}_{4} \mathrm{NO}_{3}\left(3.74 \pm 0.18 \mathrm{~m}^{2} \mathrm{~g}^{-1}\right)$ and $\left(\mathrm{NH}_{4}\right)_{2} \mathrm{SO}_{4}\left(7.35 \pm 0.25 \mathrm{~m}^{2} \mathrm{~g}^{-1}\right)$ during the normal period were higher than those $\left(3.23 \pm 0.18 \mathrm{~m}^{2} \mathrm{~g}^{-1}\right.$ and $\left.4.78 \pm 0.35 \mathrm{~m}^{2} \mathrm{~g}^{-1}\right)$ during the lockdown period. This may be explained by the higher mass loadings and peak diameters of aerosol without control measures (Cheng et al., 2015; Tao et al., 2015). The MAE of BC decreased from $15.00 \mathrm{~m}^{2} \mathrm{~g}^{-1}$ to $13.27 \mathrm{~m}^{2} \mathrm{~g}^{-1}$ that related to the decline of AAE of BC (Text S1). The MSEs and MAEs of OA factors varied widely, from $3.48 \mathrm{~m}^{2} \mathrm{~g}^{-1}$ to $12.89 \mathrm{~m}^{2} \mathrm{~g}^{-1}$ and from $0.25 \mathrm{~m}^{2} \mathrm{~g}^{-1}$ to $0.59 \mathrm{~m}^{2} \mathrm{~g}^{-1}$, respectively, due to the complex chemical variability of OA constituents (Hallquist et al., 2009; Moise et al., 2015). The scattering ability of OA increased with oxidation level (from POA to MO-OOA) (Cappa et al., 2011; Flores et al., 2014); however, the dependence on oxidation level of OA MAEs presented more complex trend. LO-OOA had the higher MAE values than those of POA, indicating more $\mathrm{BrC}$ chromophores with stronger light-absorbing capacity formed under lessoxidized condition (Zhang et al., 2020). Additionally, the effect of photo-bleaching in the atmosphere that can weaken the light absorption ability of $\mathrm{BrC}$ that resulted in the reduction of MO-OOA MAEs (Wang et al., 2021).

245 Chemical calculation of $b_{\text {ext }}$ was confirmed to be a reasonable estimation of aerosol optical coefficients by using chemical components data (Figure S10 and S11). As shown in Figure 2, OA (POA + LO-OOA + MO-OOA) was the largest contributor to $b_{\text {ext }}$ in both periods, accounting for 45.1-61.4\%, followed by $\mathrm{NH}_{4} \mathrm{NO}_{3}(16.5-24.1 \%), \mathrm{BC}(9.3-13.1 \%)$, $\left(\mathrm{NH}_{4}\right)_{2} \mathrm{SO}_{4}(7.9-11.2 \%)$, and fine soil (4.9-6.5\%). This result was different from previous findings that SIA was often the largest contributor to $b_{\text {ext }}$ in China, such as Beijing (46-54\%) (Han et al., 2015), Chengdu (43\%) (Tao et al., 2014),

250 Nanjing (53\%) (Shen et al., 2014), and Xi' an (63\%) (Cao et al., 2012), highlighting the dominant role of organic matters in aerosol light extinction in $\mathrm{Xi}$ ' an today. Compared to the normal period, the contributions of $\mathrm{NH}_{4} \mathrm{NO}_{3},\left(\mathrm{NH}_{4}\right)_{2} \mathrm{SO}_{4}$, fine soil, and $\mathrm{BC}$, and POA to $b_{\text {ext }}$ decreased by $1.3-7.6 \%$ in the lockdown, whereas contributions of two SOAs to $b_{\text {ext }}$ increased by $3.0-14.6 \%$. On the one hand, the mass concentrations of LO-OOA and MO-OOA decreased by $20.9-34.7 \%$ from normal to lockdown periods, lower than those of other chemical species (35.8-72.5\%); On the other hand, both of SOAs MSEs and MAEs showed higher values during the lockdown period, especially MO-OOA. The combination of effects eventually led to an enhanced role of SOA in light extinction during the lockdown.

\subsection{Contribution of sources to $b_{\text {ext }}$}

The 6-factor solution was selected to be the optimal solution, which can adequately account for the variability in aerosol $b_{\text {ext }}$ (Figure S12). Six sources were determined by the HERM analysis, consisting of traffic-related emission, biomass burning, coal combustion, fugitive dust, nitrate plus SOA source, and sulfate plus SOA source. Details about their characteristics are presented in Figure 3. The first source identified as traffic-related emission was characterized by high 
EV values of $\mathrm{Cr}(77 \%), \mathrm{Mn}$ (53\%), $\mathrm{Fe}(36 \%)$, and $\mathrm{Zn}(39 \%)$, which can be released from lubricating oils, fuel additives, and brake and tire wear (Ålander et al., 2005; Geivanidis et al., 2003; Tao et al., 2017; Zhang et al., 2013). Moderate contributions of POA (26\%) and BC (28\%) were commonly regarded as species of diesel and gasoline engine exhaust (Chow et al., 2004; Liu et al., 2017). Additionally, the temporal variations in $b_{\text {ext }}$ from this source correlated well with $\mathrm{NO}_{x}\left(\mathrm{R}^{2}=0.72\right)$, suggesting an association with motor vehicle emissions (Huang et al., 2017; Li et al., 2017). The second source with high EV values of POA (45\%), LO-OOA (41\%), BC (32\%), Cl (34\%), and K (41\%) was judged to biomass burning. K were regarded as an excellent tracer of biomass burning (Li et al., 2007; Ni et al., 2017), and good correlations were also found between $b_{\text {ext }}$ from biomass burning and $\mathrm{K}\left(\mathrm{R}^{2}=0.64\right)$. Previous studies have shown that POA from biomass burning can be rapidly oxidized in the atmosphere (Cubison et al., 2011), therefore, the abundant LO-OOA observed in this source might be indicative of aged biomass-burning aerosol (Crippa et al., 2013; Kim et al., 2017; Xu et al., 2015). The third source, coal combustion, was characterized by high EV values of $\mathrm{Cl}$ (42\%), As (38\%), Se (46\%), and $\mathrm{Pb}(25 \%)$. Of these elements, As and Se had been found to be enriched in coals (Tian et al., 2013), which were reliable indicators for coal combustion (Tan et al., 2017; Yu et al., 2019); and $\mathrm{Pb}$ was found to possibly emitted from coal combustion in Xi' an (Xu et al., 2012). The fourth source was defined as fugitive dust due to significant EV values of $\mathrm{Si}(92 \%), \mathrm{Ca}(63 \%)$, and $\mathrm{Fe}(31 \%)$, which were the dominant chemical species in natural and construction dust profiles (Liu et al., 2017; Zhao et al., 2006). Two secondary sources were resolved in our study as nitrate plus SOA source with high EV values of $\mathrm{NO}_{3}{ }^{-}(42 \%), \mathrm{NH}_{4}{ }^{+}(33 \%)$, and MO-OOA (34\%) and sulfate plus SOA source with high EV values of $\mathrm{SO}_{4}{ }^{2-}(58 \%)$ and MO-OOA (39\%), respectively. Since $\mathrm{SO}_{2}$ oxidation to sulfate need long time (e.g., 1 week) at the typical atmospheric level of $\mathrm{OH}$ radicals, $\mathrm{SO}_{4}{ }^{2-}$ was likely associated with regional source, while $\mathrm{NO}_{3}{ }^{-}$was often formed more locally due to the intense $\mathrm{NO}_{x}$ emissions in China (Zhang et al., 2015; Zheng et al., 2014). The defined nitrate and sulfate plus SOA sources appeared to have stronger associations with local and regional processes, respectively.

As shown in Figure 4, the average $b_{\text {ext }}$ from traffic-related emission, coal combustion and fugitive dust decreased from $77.3 \pm 46.8 \mathrm{Mm}^{-1}, 73.6 \pm 60.9 \mathrm{Mm}^{-1}$, and $93.3 \pm 82.7 \mathrm{Mm}^{-1}$ during the normal period to $1.7 \pm 4.0 \mathrm{Mm}^{-1}, 38.5 \pm 34.5 \mathrm{Mm}^{-}$ , and $30.8 \pm 24.4 \mathrm{Mm}^{-1}$ during the lockdown period, respectively, which can be explained by traffic restriction, closure of industries and stopping construction activities. $b_{\text {ext }}$ from traffic-related emission with the largest reduction (97.9\%) emphasized the effectiveness of controlling private gasoline cars and commercial and construction diesel trucks in the lockdown (Wang et al., 2020c). For two secondary sources, though previous studies reported the enhancement of secondary aerosol formation efficiencies as the increase of atmospheric oxidation capacity in the lockdown (Huang et al., 2020; Le et al., 2020; Tian et al., 2021), the decreases in gas and organic precursors (e.g., $\mathrm{NO}_{2}, \mathrm{SO}_{2}$, and VOCs) led to the $47.5 \%$ and $21.4 \%$ reductions of $b_{\text {ext }}$ from sources of nitrate plus SOA and sulfate plus SOA, respectively. That is, the enhanced secondary aerosol cannot offset the primary emission reduction in Xi'an, confirming that reducing anthropogenic primary emissions is still the most effective treatment of aerosol pollution. 
By contrast, the average $b_{\text {ext }}$ from biomass burning during the lockdown period $\left(215.4 \pm 163.9 \mathrm{Mm}^{-1}\right)$ was higher than that during the normal period $\left(169.4 \pm 196.9 \mathrm{Mm}^{-1}\right)$. The government didn't strengthen the past control policies that forbade biomass burning in the lockdown. Moreover, strict controls were enforced on the movements of people, even in the countryside, possibly resulting more consumption of biomass for cooking and heating. As shown in Figure 5, the rising stages of $\mathrm{PM}_{2.5}$ during the lockdown period were all accompanied by the increase in $b_{\text {ext }}$ from biomass burning, accounting for 46.4-55.6\% of the total $b_{\text {ext }}$. Take the rising stage of $\mathrm{PM}_{2.5}$ from 13:00 30 to 7:00 31 January as an example, $b_{\text {ext }}$ from POA and LO-OOA increased rapidly at rates of $8.6 \mathrm{Mm}^{-1}$ hour ${ }^{-1}$ and $8.2 \mathrm{Mm}^{-1}$ hour ${ }^{-1}$, respectively. Correspondingly, $b_{\text {ext }}$ from biomass burning showed the fastest rise $\left(26.0 \mathrm{Mm}^{-1}\right.$ hour $\left.^{-1}\right)$ in all primary source, that led to biomass burning became the most important source to $b_{\text {ext }}(36.7 \%)$ in the lockdown (Figure 4). Hence, additional actions and investigations on biomass burning emissions would be taken into consideration.

\subsection{Impacts of COVID-19 lockdown on aerosol DRE}

305 Figure 6 shows the range of source-specific aerosol $\mathrm{DRE}_{\mathrm{top}}, \mathrm{DRE}_{\text {surface}}$, and $\mathrm{DRE}_{\text {atmosphere }}$ during the normal and lockdown periods. For all sources, the aerosol DRE atmosphere values in both periods were positive, producing net warming effects in

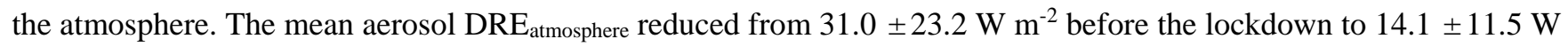
$\mathrm{m}^{-2}$ in the lockdown, with a reduction of $54.5 \%$.

With regard to the contributions of specific sources on the $\mathrm{DRE}_{\text {atmosphere, }}$ traffic-related emission had the largest positive 310 effect on $\mathrm{DRE}_{\text {atmosphere }}$ during the normal period, with the value of $13.3 \pm 9.2 \mathrm{~W} \mathrm{~m}^{-2}$, followed by biomass burning (8.4 $\left.\pm 13.0 \mathrm{~W} \mathrm{~m}^{-2}\right)$, coal combustion $\left(7.8 \pm 7.2 \mathrm{~W} \mathrm{~m}^{-2}\right)$, sulfate plus SOA source $\left(1.7 \pm 3.0 \mathrm{~W} \mathrm{~m}^{-2}\right)$, and fugitive dust $(1.1 \pm$ $\left.2.4 \mathrm{~W} \mathrm{~m}^{-2}\right)$. Nitrate and plus SOA source presented the negative value of DRE atmosphere $\left(-1.2 \pm 0.7 \mathrm{~W} \mathrm{~m}^{-2}\right)$, suggesting the cooling effect in the atmosphere. Due to the strictest traffic restrictions implemented, the DRE atmosphere from trafficrelated emission $\left(0.4 \pm 1.0 \mathrm{~W} \mathrm{~m}^{-2}\right)$ showed the significant reduction $(97.0 \%)$ in the lockdown. However, the DRE atmosphere

315 from biomass burning increased to $10.0 \pm 10.9 \mathrm{~W} \mathrm{~m}^{-2}$, indicating that biomass burning was not effectively controlled during the lockdown period. The other four sources contributed relatively small amounts of $\mathrm{DRE}_{\text {atmosphere; }}$ that is $4.5 \pm$ $4.5 \mathrm{~W} \mathrm{~m}^{-2}$ for coal combustion, $-0.3 \pm 0.8 \mathrm{~W} \mathrm{~m}^{-2}$ for fugitive dust, $-1.4 \pm 0.8 \mathrm{~W} \mathrm{~m}^{-2}$ for nitrate plus SOA source, and 1.0 $\pm 1.8 \mathrm{~W} \mathrm{~m}^{-2}$ for sulfate plus SOA source. The results indicated that the control measures on traffic in the lockdown were highly effective for mitigating the effects of climate change in short-term, while future emission control policies should consider the importance of biomass burning to tackle climate change in China. 


\section{Conclusion}

This study conducted an intensive real-time measurement campaign in an urban city of China before and during the lockdown of Coronavirus Disease 2019 to investigate the impacts of anthropogenic emissions on aerosol optical properties and direct radiative effect (DRE). Decreases in light scattering coefficient $\left(b_{\text {scat }}\right.$ ), light absorption coefficient $\left(b_{\text {abs }}\right)$, and light extinction coefficient $\left(b_{\text {ext }}\right)$ were observed in the lockdown with reductions of $27.6-47.0 \%$, in accord with the decline of $\mathrm{PM}_{2.5}$ under strict emission control measures. Single scattering albedo during the lockdown period $(0.92 \pm 0.02)$ was higher than that during the normal period $(0.89 \pm 0.03)$, suggesting an enhanced role of secondary formation in the lockdown. The generalized addictive model analysis showed that meteorological conditions enhanced $b_{\text {ext }}$ by $64.2 \mathrm{Mm}^{-1}$ during the lockdown period, thus, the dramatical reduction of $b_{\text {ext }}$ was totally credited to anthropogenic emission reductions.

The relationship between $b_{\text {ext }}$ and chemical components was established based on the ridge regression analysis. Using the estimated mass scattering and absorption efficiencies (MSEs and MAEs) of chemical components, OA including primary OA, less-, and more-oxidized oxygenated OA was found to be the largest contributor (45.1-61.4\%) to $b_{\text {ext }}$ before and during the lockdown period, followed by $\mathrm{NH}_{4} \mathrm{NO}_{3}(16.5-24.1 \%), \mathrm{BC}(9.3-13.1 \%),\left(\mathrm{NH}_{4}\right)_{2} \mathrm{SO}_{4}(7.9-11.2 \%)$, and

335 fine soil (4.9-6.5\%). Particularly, secondary OA played an increasingly important part in light extinction during the lockdown when contributions of two oxygenated OAs to $b_{\text {ext }}$ increased by 3.0-14.6\%.

A hybrid environmental receptor model coupled with chemical and optical variables was utilized to carried out optical source apportionment. Six sources of $b_{\text {ext }}$ were resolved, including traffic-related emission, biomass burning, coal combustion, fugitive dust, nitrate plus SOA source, and sulfate plus SOA source. Most of sources showed reductions of $b_{\text {ext }}$ (21.4-97.9\%) during the lockdown, confirming the effectiveness of reducing anthropogenic primary emissions for treating aerosol pollution. $b_{\text {ext }}$ from traffic-related emission had the most evident decrement (97.9\%), whereas that from biomass burning increased by $27.1 \%$ during the lockdown due to the undiminished needs of residential cooking and heating in winter.

The atmospheric radiative transfer further illustrated that aerosol produced net warming effects $\left(14.1-31.0 \mathrm{~W} \mathrm{~m}^{-2}\right)$ in the atmosphere during the normal and lockdown periods. Biomass burning instead of traffic-related emission became the largest positive effect $\left(10.0 \pm 10.9 \mathrm{~W} \mathrm{~m}^{-2}\right)$ on aerosol DRE in the atmosphere in the lockdown. The results implied that reducing biomass burning would be another direct and effective way on climate change mitigation besides traffic restriction, therefore, Chinese government should further tighten the policy on controlling biomass burning in the future. 
Data availability. Data used to support the findings in this study are archived at the Institute of Earth Environment, Chinese Academy of Sciences, and are publicly available at https://doi.org/10.5281/zenodo.5739349.

Competing interests. The authors declare that they have no conflict of interest.

Author contributions. QW, YH, and JC designed the campaign. SL, YZ, and WR conducted field measurements. JT, HL, and YM made data analysis and interpretation. JT wrote the paper with contributions from all co-authors.

Acknowledgments. The authors are grateful to the staff from Guanzhong Plain, Eco-environmental Change and

Comprehensive Treatment, National Observation and Research Station for their assistance with field sampling.

Financial support. This research was jointly supported by the Key Research and Development Program of Shaanxi Province (grant no. 2018-ZDXM3-01), the Strategic Priority Research Program of Chinese Academy of Sciences (grant no. XDB40000000), the West Light Foundation of the Chinese Academy of Sciences (grant no. XAB2019B05), the Sino-Swiss Cooperation on Air Pollution Source Apportionment for Better Air (grant no. 7F-09802.01.02), and the Youth Innovation Promotion Association of the Chinese Academy of Sciences (grant no. 2019402).

\section{References}

Ålander, T., Antikainen, E., Raunemaa, T., Elonen, E., Rautiola, A., and Torkkell, K.: Particle emissions from a small two-stroke engine: Effects of fuel, lubricating oil, and exhaust aftertreatment on particle characteristics, Aerosol Sci. Tech., 39, 151-161, https://doi.org/1 0.1080/027868290910224, 2005.

Andreae, M. O. and Gelencsér, A.: Black carbon or brown carbon? The nature of light-absorbing carbonaceous aerosols, Atmos. Chem. Phys., 6, 3131-3148, https://doi.org/10.5194/acp-6-3131-2006, 2006.

Bellouin, N., Quaas, J., Morcrette, J. J., and Boucher, O.: Estimates of aerosol radiative forcing from the MACC reanalysis, Atmos. Chem. Phys., 13, 2045-2062, https://doi.org/10.5194/acp-13-2045-2013, 2013.

Cao, J. J., Wang, Q. Y., Chow, J. C., Watson, J. G., Tie, X. X., Shen, Z. X., Wang, P., and An, Z. S.: Impacts of aerosol compositions on visibility impairment in Xi'an, China, Atmos. Environ., 59, 559-566, https://doi.org/10.1016/j.atmosenv.2012.05.036, 2012.

Cappa, C. D., Che, D. L., Kessler, S. H., Kroll, J. H., and Wilson, K. R.: Variations in organic aerosol optical and hygroscopic properties upon heterogeneous OH oxidation, J. Geophys. Res.-Atmos., 116, D15204, https://doi.org/10.1029/2011JD015918, 2011.

Chamberlain-Ward, S. and Sharp, F.: Advances in Nephelometry through the Ecotech Aurora Nephelometer, The Scientific World Journal, 11, 2530-2535, https://doi.org/10.1100/2011/310769, 2011.

Chen, L. W. and Cao, J.: PM$_{2.5}$ source apportionment using a Hybrid Environmental Receptor Model, Environ. Sci. Technol., 52, 6357-6369, https://doi.org/10.1021/acs.est.8b00131, 2018.

Chen, Y., Zhang, S. M., Peng, C., Shi, G. M., Tian, M., Huang, R. J., Guo, D. M., Wang, H. B., Yao, X. J., and Yang, F. M.: Impact of the COVID-19 pandemic and control measures on air quality and aerosol light absorption in southwestern China, Sci. Total Environ., 749, 141419, https://doi.org/10.1016/j.scitotenv.2020.141419, 2020.

Cheng, Z., Jiang, J. K., Chen, C. H., Gao, J., Wang, S. X., Watson, J. G., Wang, H. L., Deng, J. G., Wang, B. Y., Zhou, M., Chow, J. C., Pitchford, M. L., and Hao, J. M.: Estimation of aerosol mass scattering efficiencies under high mass loading: Case study for the megacity of Shanghai, China, Environ. Sci. Technol., 49, 831-838, https://doi.org/10.1021/es504567q, 2015. 
China National Environmental Monitoring Centre (CNEMC).: Background values of soil elements in China, Chinese Environmental Press, Beijing (in Chinese), 1990.

Chow, J. C., Lowenthal, D. H., Chen, L. W. A., Wang, X. L., and Watson, J. G.: Mass reconstruction methods for PM 2.5 : a review, Air Qual. Atmos. Health, 8, 243-263, https://doi.org/10.1007/s11869-015-0338-3, 2015.

Chow, J. C., Watson, J. G., Kuhns, H., Etyemezian, V., Lowenthal, D. H., Crow, D., Kohl, S. D., Engelbrecht, J. P., and Green, M. C.: Source profiles for industrial, mobile, and area sources in the Big Bend Regional Aerosol Visibility and Observational study, Chemosphere, 54, 185-208, https://doi.org/10.1016/j.chemosphere.2003.07.004, 2004.

Crippa, M., DeCarlo, P. F., Slowik, J. G., Mohr, C., Heringa, M. F., Chirico, R., Poulain, L., Freutel, F., Sciare, J., Cozic, J., Di Marco, C. F., Elsasser, M., Nicolas, J. B., Marchand, N., Abidi, E., Wiedensohler, A., Drewnick, F., Schneider, J., Borrmann, S., Nemitz, E., Zimmermann, R., Jaffrezo, J. L., Prévôt, A. S. H., and Baltensperger, U.: Wintertime aerosol chemical composition and source apportionment of the organic fraction in the metropolitan area of Paris, Atmos. Chem. Phys., 13, 961-981, https://doi.org/10.5194/acp-13-961-2013, 2013.

Cubison, M. J., Ortega, A. M., Hayes, P. L., Farmer, D. K., Day, D., Lechner, M. J., Brune, W. H., Apel, E., Diskin, G. S., Fisher, J. A., Hecobian, A., Knapp, D. J., Mikoviny, T., Riemer, D., Sachse, G. W., Sessions, W., Weber, R. J., Weinheimer, A. J., and Jimenez, J. L.: Effects of aging on organic aerosol from open biomass burning smoke in aircraft and lab studies, Atmos. Chem. Phys., 11, 12049-12064, https://doi.org/10.5194/acpd-11-12103-2011, 2011.

Deng, J. J., Zhang, Y. R., Hong, Y. W., Xu, L. L., Chen, Y. T., Du, W. J., and Chen, J. S.: Optical properties of PM 2.5 and the impacts of chemical compositions in the coastal city Xiamen in China, Sci. Total Environ., 557-558, 665675, https://doi.org/10.1016/j.scitotenv.2016.03.143, 2016.

Drinovec, L., Močnik, G., Zotter, P., Prévôt, A. S. H., Ruckstuhl, C., Coz, E., Rupakheti, M., Sciare, J., Müller, T., Wiedensohler, A., and Hansen, A. D. A.: The "dual-spot" Aethalometer: an improved measurement of aerosol black carbon with real-time loading compensation, Atmos. Meas. Tech., 8, 1965-1979, https://doi.org/10.5194/amt-81965-2015, 2015.

Feng, Y., Ramanathan, V., and Kotamarthi, V. R.: Brown carbon: a significant atmospheric absorber of solar radiation? Atmos. Chem. Phys., 13, 8607-8621, https://doi.org/10.5194/acp-13-8607-2013, 2013.

Flores, J. M., Zhao, D. F., Segev, L., Schlag, P., Kiendler-Scharr, A., Fuchs, H., Watne, A. K., Bluvshtein, N., Mentel, T. F., and Hallquist, M.: Evolution of the complex refractive index in the UV spectral region in ageing secondary organic aerosol, Atmos. Chem. Phys., 14, 5793-5806, https://doi.org/10.5194/acp-14-5793-2014, 2014.

Forello, A. C., Bernardoni, V., Calzolai, G., Lucarelli, F., Massabò, D., Nava, S., Pileci, R. E., Prati, P., Valentini, S., Valli, G., and Vecchi, R.: Exploiting multi-wavelength aerosol absorption coefficients in a multi-time resolution source apportionment study to retrieve source-dependent absorption parameters, Atmos. Chem. Phys., 19, 1123511252, https://doi.org/10.5194/acp-19-11235-2019, 2019.

Furger, M., Rai, P., Slowik, J. G., Cao, J. J., Visser, S., Baltensperger, U., and Prévôt, A. S. H.: Automated alternating sampling of $\mathrm{PM}_{10}$ and $\mathrm{PM}_{2.5}$ with an online XRF spectrometer, Atmos. Environ.: $\mathrm{X}$, 5, 100065, https://doi.org/10.1016/j.aeaoa.2020.100065, 2020.

Geivanidis, S., Pistikopoulos, P., and Samaras, Z.: Effect on exhaust emissions by the use of methylcyclopentadienyl manganese tricarbonyl (MMT) fuel additive and other lead replacement gasolines, Sci. Total Environ., 305, 129141, https://doi.org/10.1016/S0048-9697(02)00476-X, 2003.

Hallquist, M., Wenger, J. C., Baltensperger, U., Rudich, Y., Simpson, D., Claeys, M., Dommen, J., Donahue, N. M., George, C., Goldstein, A. H., Hamilton, J. F., Herrmann, H., Hoffmann, T., Iinuma, Y., Jang, M., Jenkin, M. E., Jimenez, J. L., Kiendler-Scharr, A., Maenhaut, W., McFiggans, G., Mentel, Th. F., Monod, A., Prévôt, A. S. H., Seinfeld, J. H., Surratt, J. D., Szmigielski, R., and Wildt, J.: The formation, properties and impact of secondary 
organic aerosol: current and emerging issues, Atmos. Chem. Phys., 9, 5155-5236, https://doi.org/10.5194/acp-95155-2009, 2009.

Han, T. T., Xu, W. Q., Chen, C., Liu, X. G., Wang, Q. Q., Li, J., Zhao, X. J., Du, W., Wang, Z. F., and Sun, Y. L.: Chemical apportionment of aerosol optical properties during the Asia-Pacific Economic Cooperation summit in Beijing, China, J. Geophys. Res.-Atmos., 120, 12281-12295, https://doi.org/10.1002/2015JD023918, 2015.

Herich, H., Hueglin, C., and Buchmann, B.: A 2.5 year's source apportionment study of black carbon from wood burning and fossil fuel combustion at urban and rural sites in Switzerland, Atmos. Meas. Tech., 4, 1409-1420, https://doi.org/10.5194/amt-4-1409-2011, 2011.

Hess, M., Koepke, P., and Schult, I.: Optical properties of aerosols and clouds: The software package OPAC, B. Am. Meteorol. Soc., 79, 831-844, https://doi.org/10.1175/1520-0477(1998)079<0831:OPOAAC>2.0.CO;2, 1998.

Huang, X., Ding, A. J., Gao, J., Zheng, B., Zhou, D. R., Qi, X. M., Tang, R., Wang, J. P., Ren, C. H., Nie, W., Chi, X. G., Xu, Z., Chen, L. D., Li, Y. Y., Che, F., Pang, N. N., Wang, H. K., Tong, D., Qin, W., Cheng, W., Liu, W. J., Fu, Q. Y., Liu, B. X., Chai, F., Davis, J. S., Zhang, Q., and He, K. B.: Enhanced secondary pollution offset reduction of primary emissions during COVID-19 lockdown in China, Natl. Sci. Rev., 8, nwaa137, https://doi.org/10.1093/nsr/nwaa137, 2020.

Huang, X. J., Liu, Z. R., Liu, J. Y., Hu, B., Wen, T. X., Tang, G. Q., Zhang, J. K., Wu, F. K., Ji, D. S., Wang, L. L., and Wang, Y. S.: Chemical characterization and source identification of $\mathrm{PM}_{2.5}$ at multiple sites in the Beijing-TianjinHebei region, China, Atmos. Chem. Phys., 17, 12941-12962, https://doi.org/10.5194/acp-17-12941-2017, 2017.

IPCC: Climate change 2013: The physical science basis. Contribution of working group I to the fifth assessment reprot of the intergovemental panel on climate change [Stocker, T. F., D. Qin, G. -K. Plattner, M. Tignor, S. K. Allen, J. Boschung, A. Nauels, Y. Xia, V. Bex and P.M. Midgley (eds.)]. Cambridage University Press, Cambrigde, United Kingdom and New York, NY, USA, 1535pp, 2013.

Kim, H., Zhang, Q., Bae, G. N., Kim, J. Y., and Lee, S. B.: Sources and atmospheric processing of winter aerosols in Seoul, Korea: Insights from real-Time measurements using a high-resolution aerosol mass spectrometer, Atmos. Chem. Phys., 17, 2009-2033, https://doi.org/10.5194/acp-17-2009-2017, 2017.

Kirchstetter, T.W., Novakov, T., and Hobbs, P. V.: Evidence that the spectral dependence of light absorption by aerosols is affected by organic carbon, J. Geophys. Res.-Atmos., 109, D21208, doi:10.1029/2004JD004999, 2004.

Laskin, A., Laskin, J., and Nizkorodov, S. A.: Chemistry of atmospheric brown carbon, Chem. Rev., 115, 10, 43354382, https://doi.org/10.1021/cr5006167, 2015.

Le, T. H., Wang, Y., Liu, L., Yang, J. N., Yung, Y., Li, G. H., and Seinfeld, J. H.: Unexpected air pollution with marked emission reductions during the COVID-19 outbreak in China, Science, 369, 702-706, https://doi.org/10.1126/science.abb7431, 2020.

Lee, H. J., Aiona, P. K., Laskin, A., Laskin, J., and Nizkorodov, S. A.: Effect of solar radiation on the optical properties and molecular composition of laboratory proxies of atmospheric brown carbon, Environ. Sci. Technol., 48, 1021710226, https://doi.org/10.1021/es502515r, 2014.

Li, H. Y., Zhang, Q., Zhang, Q., Chen, C. R., Wang, L. T., Wei, Z., Zhou, S., Parworth, C., Zheng, B., Canonaco, F., Prévôt, A. S. H., Chen, P., Zhang, H. L., Wallington, T. J., and He, K. B.: Wintertime aerosol chemistry and haze evolution in an extremely polluted city of the North China Plain: significant contribution from coal and biomass combustion, Atmos. Chem. Phys., 17, 4751-4768, https://doi.org/10.5194/acp-17-4751-2017, 2017.

Li, L., Li, Q., Huang, L., Wang, Q., Zhu, A. S., Xu, J., Liu, Z. Y., Li, H. L., Shi, L. S., Li, R., Azari, M., Wang, Y. J., Zhang, X. J., Liu, Z. Q., Zhu, Y. H., Zhang, K., Xue, S. H., Ooi, M. C. G., Zhang, D. P., and Chan, A.: Air quality changes during the COVID-19 lockdown over the Yangtze River Delta Region: An insight into the impact of human 
activity pattern changes on air pollution variation, Sci. Total Environ., 732, 139282, https://doi.org/10.1016/j.scitotenv.2020.139282, 2020.

Li, X. H., Wang, S. X., Duan, L., Hao, J. M., Li, C., Chen, Y. S., and Yang, L.: Particulate and trace gas emissions from open burning of wheat straw and corn stover in China, Environ. Sci. Technol., 41, 6052-6058, https://doi.org/10.1021/es0705137, 2007.

Lin, G. X., Penner, J. E., Flanner, M. G., Sillman, S., Xu, L., and Zhou, C.: Radiative forcing of organic aerosol in the atmosphere and on snow: Effects of SOA and brown carbon, J. Geophys. Res.-Atmos., 119, 7453-7476, https://doi.org/10.1002/2013JD021186, 2014.

Lin, Y. C., Zhang, Y. L., Xie, F., Fan, M. Y., and Liu, X.: Substantial decreases of light absorption, concentrations and relative contributions of fossil fuel to light-absorbing carbonaceous aerosols attributed to the COVID-19 lockdown in east China, Environ. Pollut., 275, 116615, https://doi.org/10.1016/j.envpol.2021.116615, 2021.

Liu, B. S., Wu, J. H., Zhang, J. Y., Wang, L., Yang, J. M., Liang, D. N., Dai, Q. L., Bi, X. H., Feng, Y. C., Zhang, Y. F., and Zhang, Q. X.: Characterization and source apportionment of $\mathrm{PM}_{2.5}$ based on error estimation from EPA PMF 5.0 model at a medium city in China, Environ. Pollut., 222, 10-22, https://doi.org/10.1016/j.envpol.2017.01.005, 2017.

Ma, X., Yu, F., and Luo, G.: Aerosol direct radiative forcing based on GEOS-Chem-APM and uncertainties, Atmos. Chem. Phys., 12, 5563-5581, https://doi.org/10.5194/acp-12-5563-2012, 2012.

Malm, W. C. and Hand, J. L.: An examination of the physical and optical properties of aerosols collected in the IMPROVE program, Atmos. Environ., 41, 3407-3427, https://doi.org/10.1016/j.atmosenv.2006.12.012, 2007.

Moise, T., Flores, J. M., and Rudich, Y.: Optical properties of secondary organic aerosols and their changes by chemical processes, Chem. Rev., 115, 4400-4439, https://doi.org/10.1021/cr5005259, 2015.

Ng, N. L., Herndon, S. C., Trimborn, A., Canagaratna, M. R., Croteau, P. L., Onasch, T. B., Sueper, D., Worsnop, D. R., Zhang, Q., Sun, Y. L., and Jayne, J. T.: An aerosol chemical speciation monitor (ACSM) for routine monitoring of the composition and mass concentrations of ambient aerosol, Aerosol Sci. Technol., 45, 780-794, https://doi.org/10.1080/02786826.2011.560211, 2011.

Ni, H. Y., Tian, J., Wang, X. L., Wang, Q. Y., Han, Y. M., Cao, J. J., Long, X., Chen, L.-W. A., Chow, J. C., and Watson, J. G.: $\mathrm{PM}_{2.5}$ emissions and source profiles from open burning of crop residues, Atmos. Environ., 169, 229-237, https://doi.org/10.1016/j.atmosenv.2017.08.063, 2017.

Niu, X. Y., Cao, J. J., Shen, Z. X., Ho, S. S. H., Tie, X. X., Zhao, S. Y., Xu, H. M., Zhang, T., and Huang, R. J.: PM2.5 from the Guanzhong Plain: Chemical composition and implications for emission reductions, Atmos. Environ., 147, 458-469, https://doi.org/10.1016/j.atmosenv.2016.10.029, 2016.

Norris, G., Duvall, R., Brown, S., and Bai, S.: EPA positive matrix factorization (PMF) 5.0 fundamentals and user guide, 2014.

Qin, Y. M., Tan, H. B., Li, Y. J., Li, Z. J., Schurman, M. I., Liu, L., Wu, C., and Chan, C. K.: Chemical characteristics of brown carbon in atmospheric particles at a suburban site near Guangzhou, China, Atmos. Chem. Phys., 18, 16409-16418, https://doi.org/10.5194/acp-18-16409-2018, 2018.

Rai, P., Furger, M., Slowik, J. G., Canonaco, F., Fröhlich, R., Hüglin, C., Minguillón, M. C., Petterson, K., Baltensperger, U., and Prévôt, A. S. H.: Source apportionment of highly time-resolved elements during a firework episode from a rural freeway site in Switzerland, Atmos. Chem. Phys., 20, 1657-1674, https://doi.org/10.5194/acp-20-1657-2020, 2020. 
Ricchiazzi, P., Yang, S. R., Gautier, C., and Sowle, D.: SBDART: A research and teaching software tool for Planeparallel radiative transfer in the Earth's atmosphere, B. Am. Meteorol. Soc., 79, 2101-2114, https://doi.org/10.1175/1520-0477(1998)079<2101:SARATS>2.0.CO;2, 1998.

Saarikoski, S., Niemi, J. V., Aurela, M., Pirjola, L., Kousa, A., Rönkkö, T., and Timonen, H.: Sources of black carbon at residential and traffic environments obtained by two source apportionment methods, Atmos. Chem. Phys., 21, 14851-14869, https://doi.org/10.5194/acp-21-14851-2021, 2021.

Sandradewi, J., Prévôt, A. S. H., Szidat, S., Perron, N., Alfarra, M. R., Lanz, V. A., Weingartner, E., and Baltensperger, U.: Using aerosol light absorption measurements for the quantitative determination of wood burning and traffic emission contributions to particulate matter, Environ. Sci. Technol., 42, 3316-3323, https://doi.org/10.1021/es702253m, 2008.

Schimek, M. G.: Semiparametric penalized generalized additive models for environmental research and epidemiology, Environmetrics, 20, 699-717, https://doi.org/10.1002/env.972, 2009.

Shen, G. F., Xue, M., Yuan, S. Y., Zhang, J., Zhao, Q. Y., Li, B., Wu, H. S., and Ding, A. J.: Chemical compositions and reconstructed light extinction coefficients of particulate matter in a mega-city in the western Yangtze River Delta, China, Atmos. Environ., 83, 14-20, https://doi.org/10.1016/j.atmosenv.2013.10.055, 2014.

Tan, J. H., Zhang, L. M., Zhou, X. M., Duan, J. C., Li, Y., Hu, J. N., and He, K. B.: Chemical characteristics and source apportionment of $\mathrm{PM}_{2.5}$ in Lanzhou, China, Sci. Total Environ., 601-602, 1743-1752, https://doi.org/10.1016/j.scitotenv.2017.06.050, 2017.

Tao, J., Zhang, L. M., Cao, J. J., Zhong, L. J., Chen, D. S., Yang, Y. H., Chen, D. H., Chen, L. G., Zhang, Z. S., Wu, Y., Xia, Y. J., Ye, S. Q., and Zhang, R. J.: Source apportionment of $\mathrm{PM}_{2.5}$ at urban and suburban areas of the Pearl River Delta region, south China - With emphasis on ship emissions, Sci. Total Environ., 574, 1559-1570, https://doi.org/10.1016/j.scitotenv.2016.08.175, 2017.

Tao, J., Zhang, L. M., Cao, J., Hsu, S. C., Xia, X. G., Zhang, Z. S., Lin, Z. J., Cheng, T. T., and Zhang, R. J.: Characterization and source apportionment of aerosol light extinction in Chengdu, southwest China, Atmos. Environ., 95, 552-562, https://doi.org/10.1016/j.atmosenv.2014.07.017, 2014.

Tao, J., Zhang, L. M., Gao, J., Wang, H., Chai, F. H., and Wang, S. L: Aerosol chemical composition and light scattering during a winter season in Beijing, Atmos. Environ., 110, 36-44, https://doi.org/10.1016/j.atmosenv.2015.03.037, 2015.

Tian, H. Z., Lu, L., Hao, J. M., Gao, J. J., Cheng, K., Liu, K. Y., Qiu, P. P., and Zhu, C. Y.: A review of key hazardous trace elements in Chinese coals: Abundance, occurrence, behavior during coal combustion and their environmental impacts, Energ. Fuel., 27, 601-614, https://doi.org/10.1021/ef3017305, 2013.

Tian, J., Wang, Q. Y., Han, Y. M., Ye, J. H., Wang, P., Pongpiachan, S., Ni, H. Y., Zhou, Y. Q., Wang, M., Zhao, Y. Z., and Cao, J. J.: Contributions of aerosol composition and sources to particulate optical properties in a southern coastal city of China, Atmos. Res., 235, 104744, https://doi.org/ 10.1016/j.atmosres.2019.104744, 2020.

Tian, J., Wang, Q. Y., Ni, H. Y., Wang, M., Zhou, Y. Q., Han, Y. M., Shen, Z. X., Pongpiachan, S., Zhang, N. N., Zhao, Z. Z., Zhang, Q., Zhang, Y., Long, X., and Cao, J. J.: Emission characteristics of primary brown carbon absorption from biomass and coal burning: Development of an optical emission inventory for China, J. Geophys. Res.-Atmos., 124, 1879-1893, https://doi.org/10.1029/2018JD029352, 2019.

Tian, J., Wang, Q. Y., Zhang, Y., Yan, M. Y., Liu, H. K., Zhang, N. N., Ran, W. K., and Cao, J. J.: Impacts of primary emissions and secondary aerosol formation on air pollution in an urban area of China during the COVID-19 lockdown, Environ. Int., 150, 106426, https://doi.org/10.1016/j.envint.2021.106426, 2021. 
Ulbrich, I. M., Canagaratna, M. R., Zhang, Q., Worsnop, D. R., and Jimenez, J. L.: Interpretation of organic components from Positive Matrix Factorization of aerosol mass spectrometric data, Atmos. Chem. Phys., 9, 2891-2918, https://doi.org/10.5194/acp-9-2891-2009, 2009.

Wang, J. F., Ye, J. H., Zhang, Q., Zhao, J., Wu, Y. Z., Li, J. Y., Liu, D. T., Li, W. J., Zhang, Y. G., Wu, C., Xie, C. H., Qin, Y. M., Lei, Y. L., Huang, X. P., Guo, J. P., Liu, P. F., Fu, P. Q., Li, Y. J., Lee, H. C., Choi, H., Zhang, J., Liao, H., Chen, M. D., Sun, Y. L., Ge, X. L., Martin, S. T., and Jacob, D. J.: Aqueous production of secondary organic aerosol from fossil-fuel emissions in winter Beijing haze, P. Natl. Acad. Sci. USA., 118, e2022179118, https://doi.org/10.1073/pnas.2022179118, 2021.

Wang, P., Cao, J. J., Shen, Z. X., Han, Y. M., Lee, S. C., Huang, Y., Zhu, C. S., Wang, Q. Y., Xu, H. M., and Huang, R. J.: Spatial and seasonal variations of $\mathrm{PM}_{2.5}$ mass and species during 2010 in Xi'an, China, Sci. Total Environ., 508, 477-487, https://doi.org/10.1016/j.scitotenv.2014.11.007, 2015.

Wang, P.F., Chen, K.Y., Zhu, S.Q., Wang, P., and Zhang, H.L.: Severe air pollution events not avoided by reduced anthropogenic activities during COVID-19 outbreak, Resour. Conserv. Recycl., 158, 104814, https://doi.org/10.1016/j.resconrec.2020.104814, 2020a.

Wang, Q. Y., Liu, H. K., Wang, P., Dai, W. T., Zhang, T., Zhao, Y. Z., Tian, J., Zhang, W. Y., Han, Y. M., and Cao, J. J.: Optical source apportionment and radiative effect of light-absorbing carbonaceous aerosols in a tropical marine monsoon climate zone: the importance of ship emissions, Atmos. Chem. Phys., 20, 15537-15549, https://doi.org/10.5194/acp-20-15537-2020, 2020b.

Wang, X., Heald, C. L., Ridley, D. A., Schwarz, J. P., Spackman, J. R., Perring, A. E., Coe, H., Liu, D., and Clarke, A. D.: Exploiting simultaneous observational constraints on mass and absorption to estimate the global direct radiative forcing of black carbon and brown carbon, Atmos. Chem. Phys., 14, 17527-17583, https://doi.org/10.5194/acp-1410989-2014, 2014.

Wang, Y. C., Yuan, Y., Wang, Q. Y., Liu, C. G., Zhi, Q., and Cao, J. J.: Changes in air quality related to the control of coronavirus in China: Implications for traffic and industrial emissions, Sci. Total Environ., 731, 139133, https://doi.org/10.1016/j.scitotenv.2020.139133, 2020c.

Wood, S. N.: Generalized additive models: An introduction with R (2nd ed), CRC press, 496pp, https://doi.org/10.1201/9781315370279, 2017.

Wood, S. N.: Stable and efficient multiple smoothing parameter estimation for generalized additive models, J. Am. Stat. Assoc., 99, 673-686, https://doi.org/10.1198/016214504000000980, 2004.

Wu, J. R., Bei, N. F., Li, X., Cao, J. J., Feng, T., Wang, Y. C., Tie, X. X., and Li, G. H.: Widespread air pollutants of the North China Plain during the Asian summer monsoon season: a case study, Atmos. Chem. Phys., 18, 8491-8504, https://doi.org/10.5194/acp-18-8491-2018, 2018.

Xie, M. J., Chen, X., Holder, A. L., Hays, M. D., Lewandowski, M., Offenberg, J. H., Kleindienst, T. E., Jaoui, M., and Hannigan, M. P.: Light absorption of organic carbon and its sources at a southeastern U.S. location in summer, Environ. Pollut., 244, 38-46, https://doi.org/10.1016/j.envpol.2018.09.125, 2019.

Xu, H. M., Cao, J. J., Ho, K. F., Ding, H., Han, Y. M., Wang, G. H., Chow, J. C., Watson, J. G., Khol, S. D., Qiang, J., Li, W. T.: Lead concentrations in fine particulate matter after the phasing out of leaded gasoline in Xi'an, China, Atmos. Environ., 46, 217-224, https://doi.org/10.1016/j.atmosenv.2011.09.078, 2012.

Xu, L., Zhang, J., Sun, X., Xu, S. C., Shan, M., Yuan, Q., Liu, L., Du, Z. H., Liu, D. T., Xu, D., Song, C. B., Liu, B. W., Lu, G. D., Shi, Z. B., and Li, W. J.: Variation in concentration and sources of black carbon in a megacity of China during the COVID-19 pandemic, Geophys. Res. Lett., 47, e2020GL090444, https://doi.org/10.1029/2020GL090444, 2020. 
Xu, W. Q., Sun, Y. L., Chen, C., Du, W., Han, T. T., Wang, Q. Q., Fu, P. Q., Wang, Z. F., Zhao, X. J., Zhou, L. B., Ji, D. S., Wang, P. C., and Worsnop, D. R.: Aerosol composition, oxidation properties, and sources in Beijing: results from the 2014 Asia-Pacific Economic Cooperation summit study, Atmos. Chem. Phys., 15, 13681-13698, https://doi.org/10.5194/acp-15-13681-2015, 2015.

Yao, H., Song, Y., Liu, M. X., Archer-Nicholls, S., Lowe, D., McFiggans, G., Xu, T. T., Du, P., Li, J. F., Wu, Y. S., Hu, M., Zhao, C., and Zhu, T.: Direct radiative effect of carbonaceous aerosols from crop residue burning during the summer harvest season in East China, Atmos. Chem. Phys., 17, 5205-5219, https://doi.org/10.5194/acp-17-52052017, 2017.

Yao, M. S., Zhang, L., Ma, J. X., and Zhou, L.: On airborne transmission and control of SARS-Cov-2, Sci. Total Environ., 731, 139178, https://doi.org/10.1016/j.scitotenv.2020.139178, 2020.

Yu, Y. Y., He, S. Y., Wu, X. L., Zhang, C., Yao, Y., Liao, H., Wang, Q. G., and Xie, M. J.: PM2.5 elements at an urban site in Yangtze River Delta, China: High time-resolved measurement and the application in source apportionment, Environ. Pollut., 253, 1089-1099, https://doi.org/10.1016/j.envpol.2019.07.096, 2019.

Zhang, R., Jing, J., Tao, J., Hsu, S. C., Wang, G., Cao, J., Lee, C. S. L., Zhu, L., Chen, Z., Zhao, Y., and Shen, Z.: Chemical characterization and source apportionment of $\mathrm{PM}_{2.5}$ in Beijing: seasonal perspective, Atmos. Chem. Phys., 13, 7053-7074, https://doi.org/10.5194/acp-13-7053-2013, 2013.

Zhang, R. Y., Wang, G. H., Guo, S., Zamora, M. L., Ying, Q., Lin, Y., Wang, W. G., Hu, M., and Wang, Y.: Formation of urban fine particulate matter, Chem. Rev., 115, 3803-3855, https://doi.org/10.1021/acs.chemrev.5b00067, 2015.

Zhang, Q., Shen, Z. X., Zhang, L. M., Zeng, Y. L., Ning, Z., Zhang, T., Lei, Y. L., Wang, Q. Y., Li, G. H., Sun, J., Westerdahl, D., Xu, H. M., and Cao, J. J.: Investigation of primary and secondary particulate brown carbon in two Chinese cities of Xi'an and Hong Kong in wintertime, Environ. Sci. Technol., 54, 3803 - 3813, https://doi.org/10.1021/acs.est.9b05332, 2020.

Zhao, P. S., Feng, Y. C., Tan, Z., and Wu, J. H.: Characterizations of resuspended dust in six cities of North China, Atmos. Environ., 40, 5807-5814, https://doi.org/10.1016/j.atmosenv.2006.05.026, 2006.

Zhao, Y. B., Zhang, K., Xu, X. T., Shen, H. Z., Zhu, X., Zhang, Y. X., Hu, Y. T., and Shen, G. F.: Substantial changes in nitrogen dioxide and ozone after excluding meteorological impacts during the COVID-19 outbreak in mainland China, Environ. Sci. Technol. Lett., 7, 402-408, https://doi.org/10.1021/acs.estlett.0c00304, 2020.

Zheng, B., Huo, H., Zhang, Q., Yao, Z. L., Wang, X. T., Yang, X. F., Liu, H., and He, K. B.: High-resolution mapping of vehicle emissions in China in 2008, Atmos. Chem. Phys., 14, 9787-9805, https://doi.org/10.5194/acp-14-97872014, 2014.

Zheng, B., Tong, D., Li, M., Liu, F., Hong, C. P., Geng, G. N., Li, H. Y., Li, X., Peng, L. Q., Qi, J., Yan, L., Zhang, Y. X., Zhao, H. Y., Zheng, Y. X., He, K. B., and Zhang, Q.: Trends in China's anthropogenic emissions since 2010 as the consequence of clean air actions, Atmos. Chem. Phys., 18, 14095-14111, https://doi.org/10.5194/acp-1814095-2018, 2018.

Zheng, H., Kong, S. F., Chen, N., Yan, Y. Y., Liu, D. T., Zhu, B., Xu, K., Cao, W. X., Ding, Q. Q., Lan, B., Zhang, Z. X., Zheng, M. M., Fan, Z. W., Cheng, Y., Zheng, S. R., Yao, L. Q., Bai, Y. Q., Zhao, T. L., and Qi, S. H.: Significant changes in the chemical compositions and sources of $\mathrm{PM}_{2.5}$ in Wuhan since the city lockdown as COVID-19. Sci. Total Environ., 739, 140000, https://doi.org/10.1016/j.scitotenv.2020.140000, 2020.

Zhou, Y. Q., Wang, Q. Y., Huang, R. J., Liu, S. X., Tie, X. X., Su, X. L., Niu, X. Y., Zhao, Z. Z., Ni, H. Y., Wang, M., Zhang, Y. G., and Cao, J. J.: Optical properties of aerosols and implications for radiative effects in Beijing during the Asia-Pacific Economic Cooperation (APEC) Summit 2014, J. Geophys. Res.-Atmos., 122, 10119-10132, https://doi.org/10.1002/2017jd026997, 2017. 
https://doi.org/10.5194/acp-2021-947

Preprint. Discussion started: 1 December 2021

(C) Author(s) 2021. CC BY 4.0 License.

(c) (1)

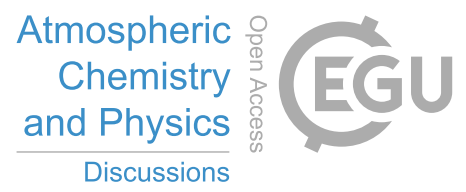

635 Zotter, P., Herich, H., Gysel, M., El-Haddad, I., Zhang, Y., Močnik, G., Hüglin, C. Baltensperger, U., Szidat, S., and Prévôt, A. S. H.: Evaluation of the absorption Ångström exponents for traffic and wood burning in the Aethalometer-based source apportionment using radiocarbon measurements of ambient aerosol, Atmos. Chem. Phys., 17, 4229-4249, https://doi.org/10.5194/acp-17-4229-2017, 2017. 
Table 1. Summary of optical coefficients and chemical species in Xi' an observed in the entire campaign, normal period (1 to 23 January), and COVID-19 lockdown period (27 January to 7 February).

\begin{tabular}{lllll}
\hline Parameters & & & \\
\hline Optical coefficients & Entire campaign & Normal period & COVID-19 lockdown period & Change ratio** $^{* *}$ \\
$b_{\text {scat }}$ & $623.2 \pm 248.3$ & $688.1 \pm 261.4$ & $498.4 \pm 159.0$ & $27.6 \%$ \\
$b_{\text {abs }}$ & $72.6 \pm 42.1$ & $86.6 \pm 43.0$ & $45.9 \pm 22.9$ & $47.0 \%$ \\
$b_{\text {ext }}$ & $695.8 \pm 285.3$ & $774.7 \pm 298.1$ & $544.3 \pm 179.4$ & $29.7 \%$ \\
SSA & $0.90 \pm 0.03$ & $0.89 \pm 0.03$ & $0.92 \pm 0.02$ & $-3.2 \%$ \\
& & & & \\
Chemical species & & & & $39.1 \%$ \\
PM $_{2.5}$ & $116.4 \pm 56.3$ & $134.4 \pm 56.9$ & $81.8 \pm 34.9$ & $51.6 \%$ \\
$\mathrm{NH}_{4} \mathrm{NO}_{3}$ & $33.1 \pm 17.3$ & $40.2 \pm 16.4$ & $19.5 \pm 8.8$ & $38.1 \%$ \\
$(\mathrm{NH} 4)_{2} \mathrm{SO}_{4}$ & $8.3 \pm 4.6$ & $9.5 \pm 4.9$ & $5.9 \pm 2.5$ & $72.5 \%$ \\
fine soil & $11.8 \pm 8.0$ & $15.8 \pm 7.2$ & $4.3 \pm 1.9$ & $50.6 \%$ \\
$\mathrm{BC}$ & $4.4 \pm 2.6$ & $5.4 \pm 2.6$ & $2.7 \pm 1.3$ & $35.8 \%$ \\
POA & $18.3 \pm 12.4$ & $20.9 \pm 12.7$ & $13.4 \pm 10.1$ & $34.7 \%$ \\
LO-OOA & $7.6 \pm 5.8$ & $8.6 \pm 6.4$ & $5.6 \pm 3.7$ & $20.9 \%$ \\
MO-OOA & $11.1 \pm 4.5$ & $12.0 \pm 4.8$ & $9.5 \pm 3.3$ &
\end{tabular}

${ }^{*}$ The units for $b_{\text {scat }}, b_{\text {abs }}, b_{\text {ext }}$ are $\mathrm{Mm}^{-1}$; SSA is dimensionless; The units of chemical species are $\mu \mathrm{g} \mathrm{m}^{-3}$.

${ }^{* *}$ Change ratio $=([$ Normal period $]-[$ COVID-19 lockdown period $]) /[$ Normal period $]$. 
Table 2. Estimated MSEs and MAEs $\left(\mathrm{m}^{2} \mathrm{~g}^{-1}\right)$ of individual chemical components during normal and COVID-19 lockdown periods.

\begin{tabular}{ccccc}
\hline \multirow{2}{*}{ Components } & \multicolumn{2}{c}{ Normal period } & \multicolumn{2}{c}{ COVID-19 lockdown period } \\
& MSE & MAE & $3.23 \pm 0.18$ & MAE \\
\hline $\mathrm{NH}_{4} \mathrm{NO}_{3}$ & $3.74 \pm 0.18$ & & $4.78 \pm 0.35$ & \\
$\left(\mathrm{NH}_{4}\right)_{2} \mathrm{SO}_{4}$ & $7.35 \pm 0.25$ & & $3.39 \pm 0.79$ & \\
fine soil & $2.46 \pm 0.35$ & 15.00 & & 13.27 \\
BC & & $0.25 \pm 0.01$ & $3.48 \pm 0.16$ & $0.29 \pm 0.01$ \\
POA & $3.90 \pm 0.18$ & $0.27 \pm 0.02$ & $9.87 \pm 0.35$ & $0.59 \pm 0.03$ \\
LO-OOA & $8.62 \pm 0.27$ & $/$ & $12.89 \pm 0.55$ & $0.31 \pm 0.04$ \\
MO-OOA & $9.87 \pm 0.45$ & &
\end{tabular}

${ }^{*} \mathrm{MAE}$ of MO-OOA during the normal period was negative (near zero) and not listed in the table. 


\section{Figure captions:}

Figure 1. Time series of the measured and GAM-predicted light extinction coefficient $\left(b_{\text {ext }}\right)$ for the model data, test data, and forecast data.

Figure 2. Contributions of $\mathrm{NH}_{4} \mathrm{NO}_{3}$, $\left(\mathrm{NH}_{4}\right)_{2} \mathrm{SO}_{4}$, fine soil, BC, POA, LO-OOA, and MO-OOA to the reconstructed chemical light extinction coefficient $\left(b_{\text {ext }}\right)$ during the normal and COVID-19 lockdown periods.

655 Figure 3. (a) Profiles and (b) time series plots of the resolved source factors in the 6-factor solution, including trafficrelated emission, biomass burning, coal combustion, fugitive dust, nitrate plus SOA source, and sulfate plus SOA source. The columns in each factor is the profile that displaying relative relation of absolute values of variables. The red dot represents the explained variation of species for different factors. The corresponding time trends of chemical tracers are also shown.

660 Figure 4. Contributions of six resolved sources to the modeled source light extinction coefficient $\left(b_{\mathrm{ext}}\right)$ during the normal and COVID-19 lockdown periods, including traffic-related emission, biomass burning, coal combustion, fugitive dust, nitrate plus SOA source, and sulfate plus SOA source.

Figure 5. Time series of $\mathrm{PM}_{2.5}$ mass concentration, the light extinction coefficient ( $\left.b_{\text {ext }}\right)$ of chemical species, and the $b_{\text {ext }}$ from six resolved sources during the lockdown period. Pie charts depicting the average fractional contributions of chemical species and sources to $b_{\text {ext }}$ during the $\mathrm{PM}_{2.5}$ rising stages, which were marked in light gray.

Figure 6. Direct radiative effect (DRE) of aerosol from traffic-related emission, biomass burning, coal combustion, fugitive dust, nitrate plus SOA source, and sulfate plus SOA source at the earth's surface, the top of the atmosphere, and in the atmosphere during the normal (a) and COVID-19 lockdown (b) periods. 


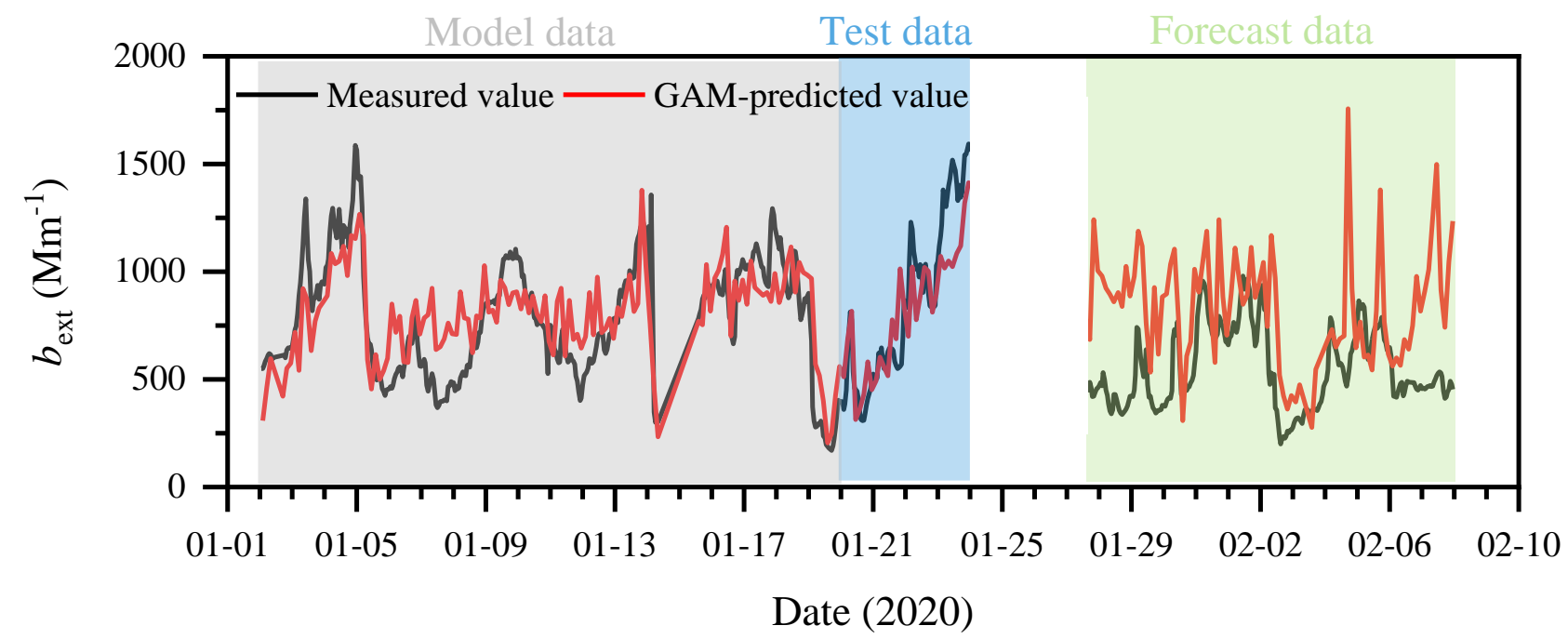

Figure 1. Time series of the measured and GAM-predicted light extinction coefficient $\left(b_{\text {ext }}\right)$ for the model data, test data, and forecast data. 


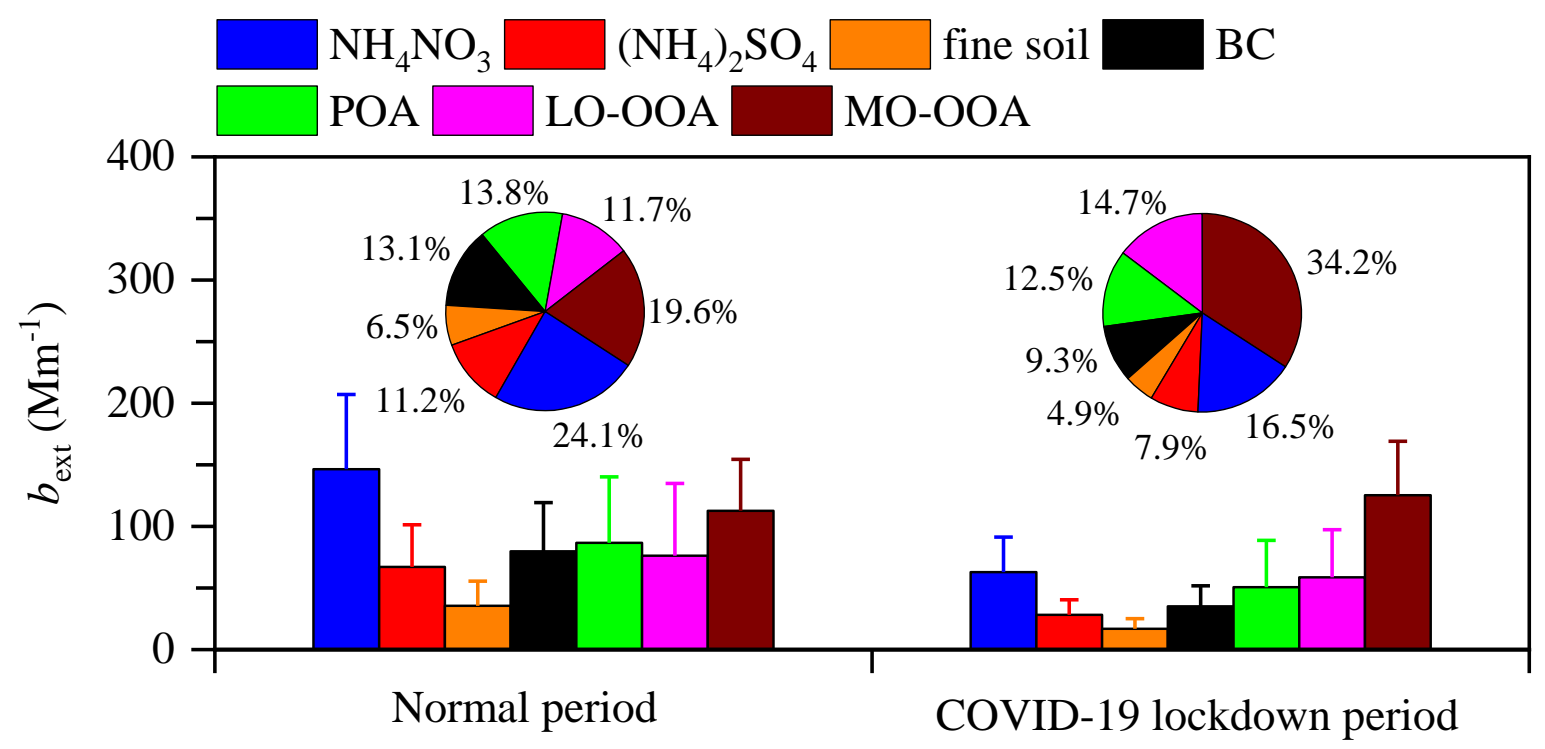

675 Figure 2. Contributions of $\mathrm{NH}_{4} \mathrm{NO}_{3},\left(\mathrm{NH}_{4}\right)_{2} \mathrm{SO}_{4}$, fine soil, $\mathrm{BC}, \mathrm{POA}$, LO-OOA, and MO-OOA to the reconstructed chemical light extinction coefficient $\left(b_{\text {ext }}\right)$ during the normal and COVID-19 lockdown periods. 


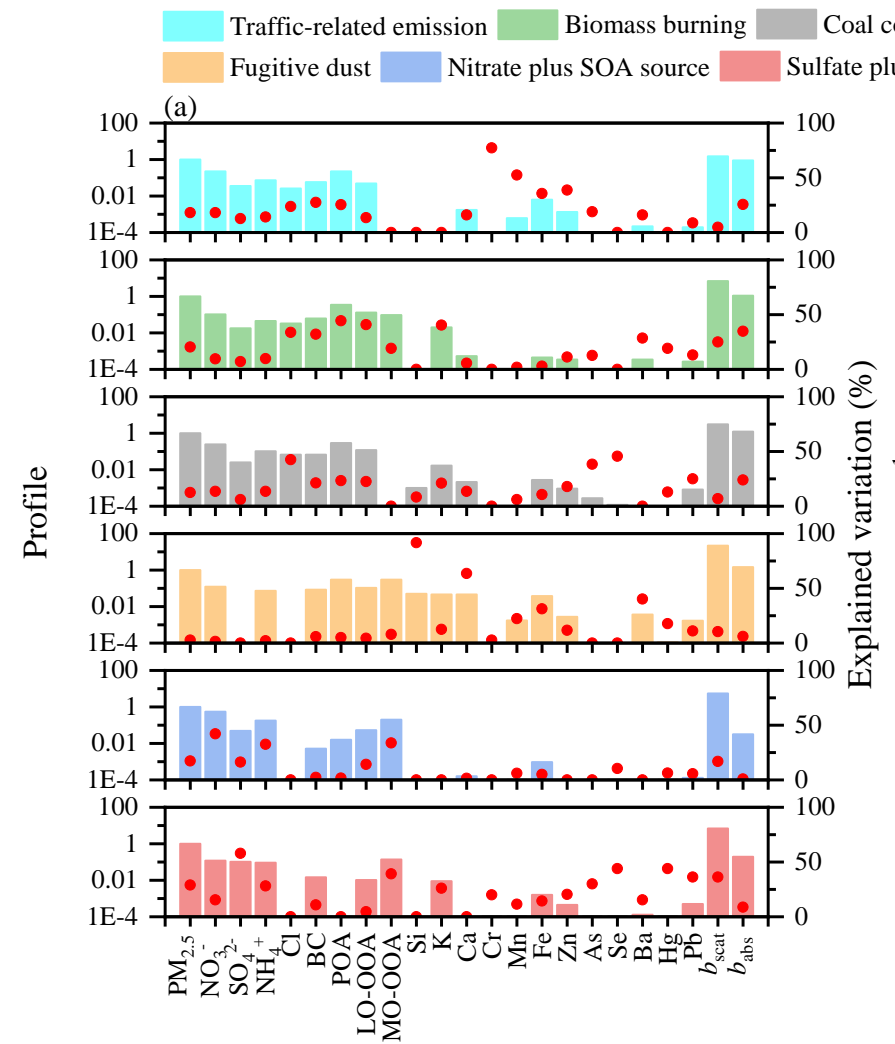

Chemical and optical variables

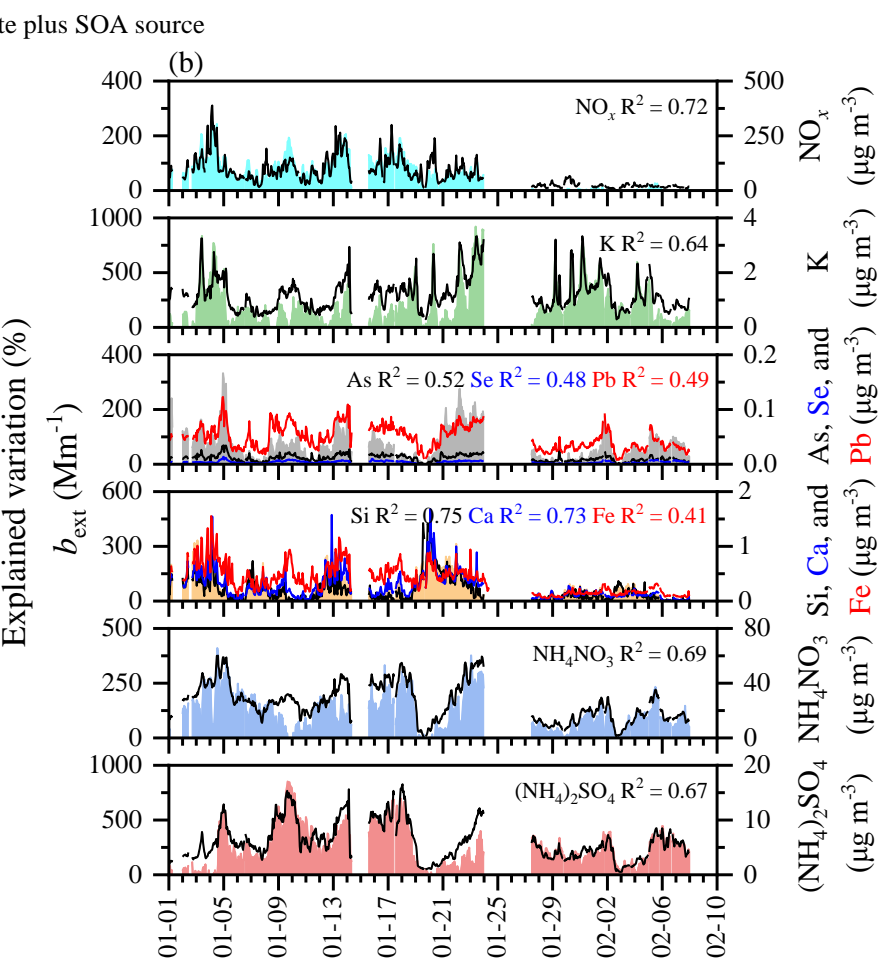

Date (2020)

Figure 3. (a) Profiles and (b) time series plots of the resolved source factors in the 6-factor solution, including trafficrelated emission, biomass burning, coal combustion, fugitive dust, nitrate plus SOA source, and sulfate plus SOA source. The columns in each factor is the profile that displaying relative relation of absolute values of variables. The red dot represents the explained variation of species for different factors. The corresponding time trends of chemical tracers are also shown. 


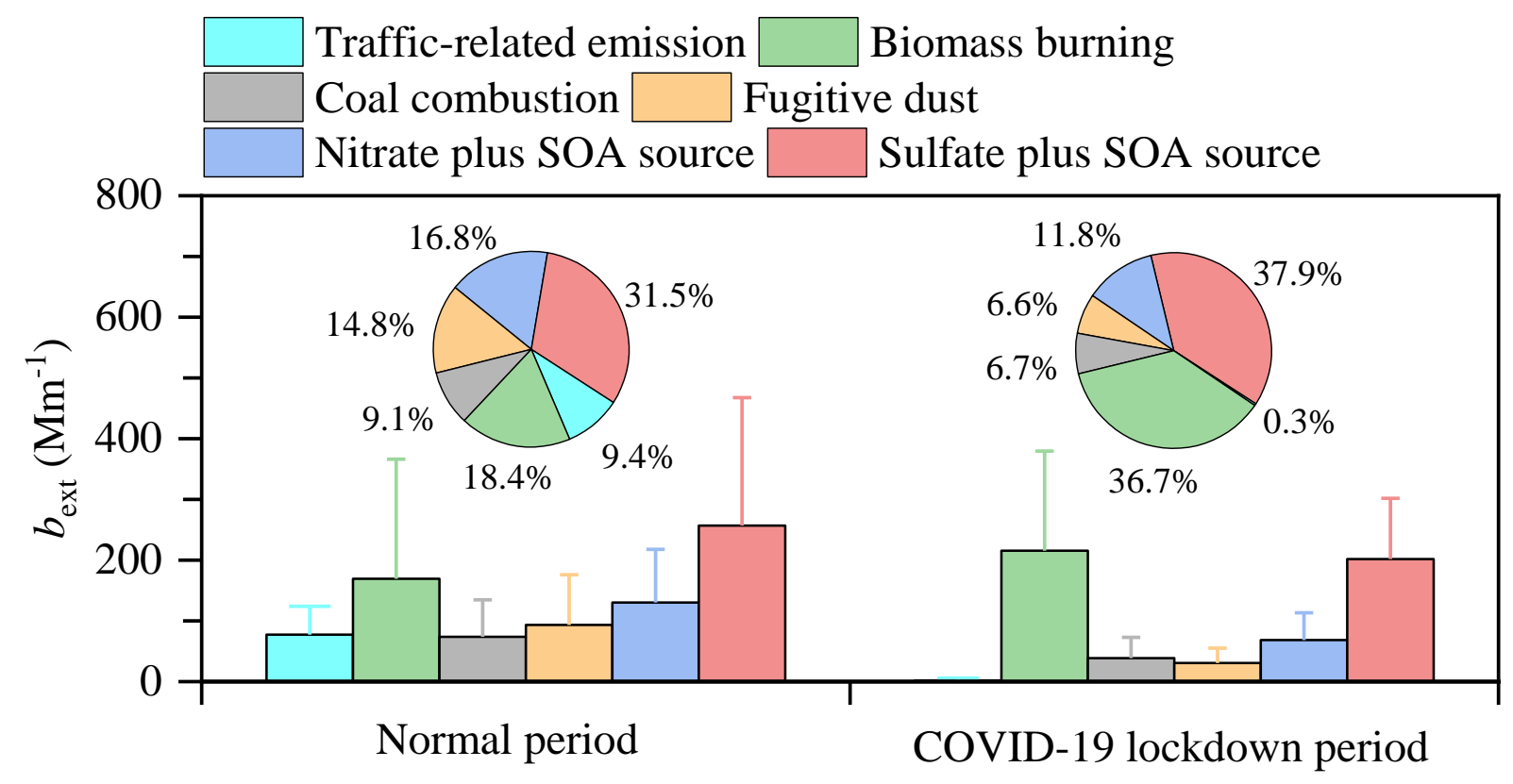

Figure 4. Contributions of six resolved sources to the modeled source light extinction coefficient $\left(b_{\text {ext }}\right)$ during the normal and COVID-19 lockdown periods, including traffic-related emission, biomass burning, coal combustion, fugitive dust, nitrate plus SOA source, and sulfate plus SOA source. 


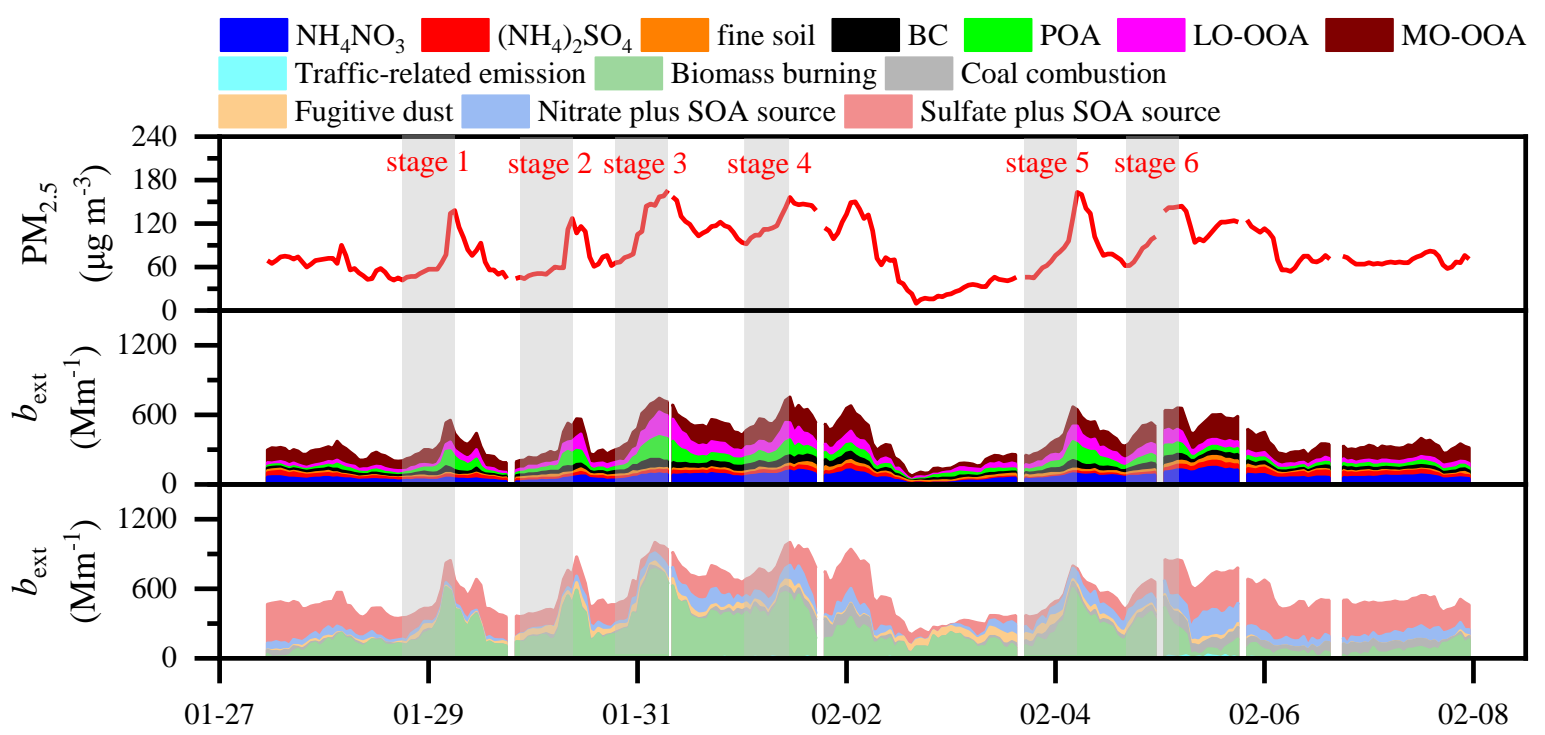

Date (2020)

stage 1
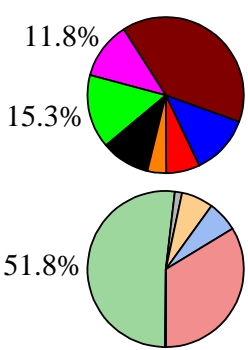

stage 2

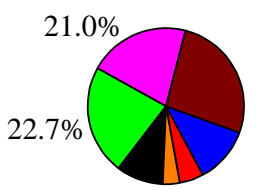

stage 3
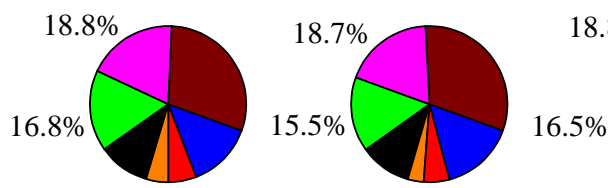

stage 5
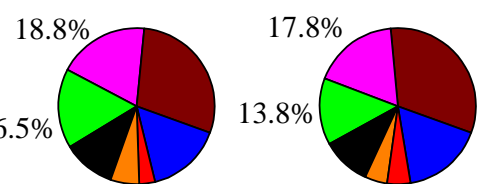

$54.3 \%$
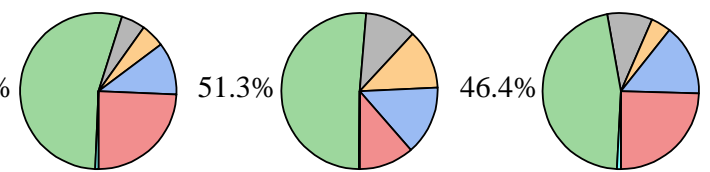

Figure 5. Time series of $\mathrm{PM}_{2.5}$ mass concentration, the light extinction coefficient ( $b_{\text {ext }}$ ) of chemical species, and the $b_{\text {ext }}$ from six resolved sources during the lockdown period. Pie charts depicting the average fractional contributions of chemical species and sources to $b_{\text {ext }}$ during the $\mathrm{PM}_{2.5}$ rising stages, which were marked in light gray. 
(a) Normal period

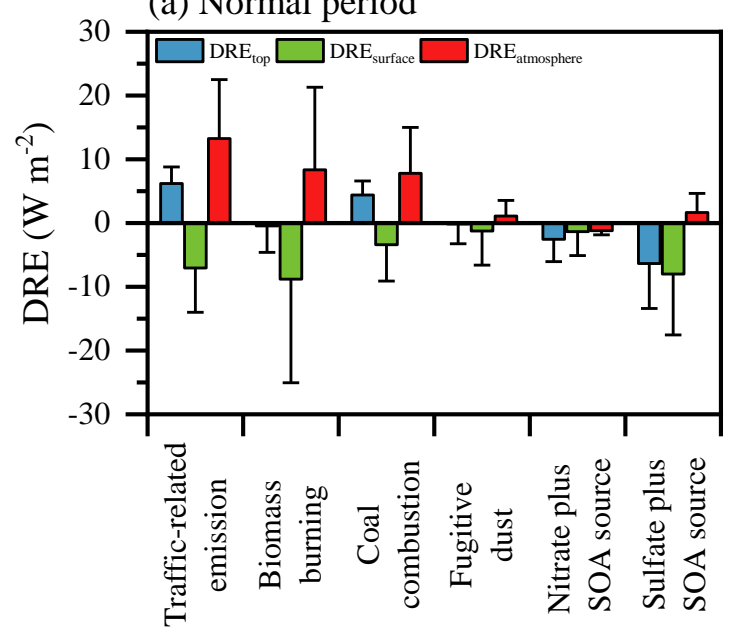

Source (b) COVID-19 lockdown period

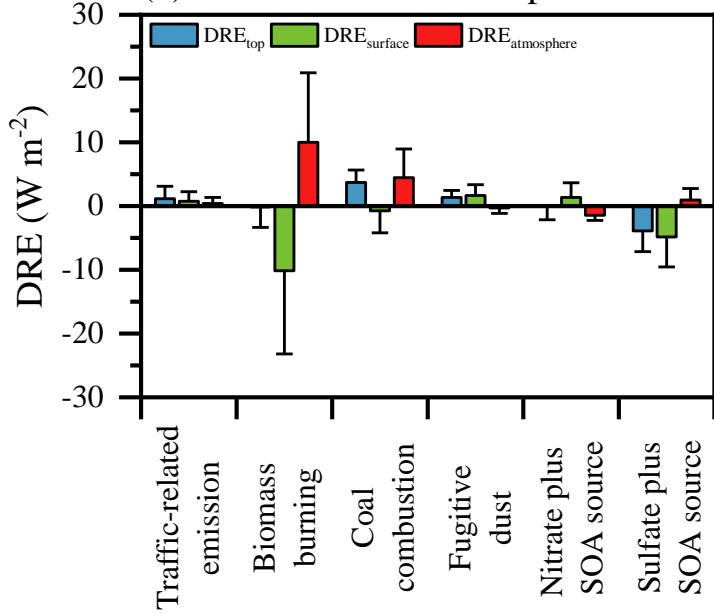

Source

Figure 6. Direct radiative effect (DRE) of aerosol from traffic-related emission, biomass burning, coal combustion, fugitive dust, nitrate plus SOA source, and sulfate plus SOA source at the earth's surface, the top of the atmosphere, and in the atmosphere during the normal (a) and COVID-19 lockdown (b) periods. 